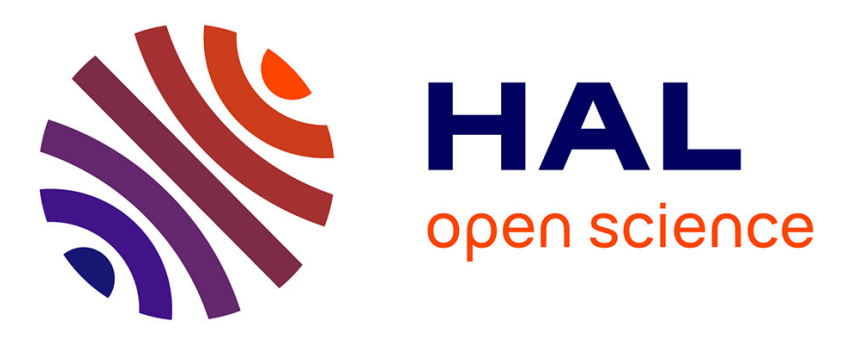

\title{
Evidence for the systemic diffusion of (2-chloroethyl)-ethyl-sulfide, a sulfur mustard analog, and its deleterious effects in brain
}

Marie Gilardoni, Daniel Léonço, Fanny Caffin, Fanny Gros-Désormeaux, Camille Eldin, David Béal, Sadia Ouzia, Christophe Junot, François Fenaille, Christophe Piérard, et al.

\section{To cite this version:}

Marie Gilardoni, Daniel Léonço, Fanny Caffin, Fanny Gros-Désormeaux, Camille Eldin, et al.. Evidence for the systemic diffusion of (2-chloroethyl)-ethyl-sulfide, a sulfur mustard analog, and its deleterious effects in brain. Toxicology, 2021, 462, 10.1016/j.tox.2021.152950 . hal-03345961

\author{
HAL Id: hal-03345961 \\ https://hal.science/hal-03345961
}

Submitted on 17 Sep 2021

HAL is a multi-disciplinary open access archive for the deposit and dissemination of scientific research documents, whether they are published or not. The documents may come from teaching and research institutions in France or abroad, or from public or private research centers.
L'archive ouverte pluridisciplinaire HAL, est destinée au dépôt et à la diffusion de documents scientifiques de niveau recherche, publiés ou non, émanant des établissements d'enseignement et de recherche français ou étrangers, des laboratoires publics ou privés. 
Evidence for the systemic diffusion of (2-chloroethyl)-ethyl-sulfide, a sulfur mustard analog, and its deleterious effects in brain

By Marie Gilardoni ${ }^{1}$, Daniel Léonço², Fanny Caffin ${ }^{3}$, Fanny Gros-Désormeaux ${ }^{3}$, Camille Eldin ${ }^{1}$, David Béal ${ }^{1}$, Sadia Ouzia ${ }^{2}$, Christophe Junot ${ }^{2}$, François Fenaille ${ }^{2}$, Christophe Piérard ${ }^{3}$ and Thierry Douki ${ }^{1 *}$

1) Univ. Grenoble Alpes, CEA, CNRS, IRIG, SyMMES, F-38000 Grenoble

2) Université Paris-Saclay, CEA, INRAE, Département Médicaments et Technologies pour la Santé (DMTS), MetaboHUB, F-91191 Gif sur Yvette, France

3) Institut de Recherche Biomédicale des Armées (IRBA), Place Général Valérie André, BP 73, 91223 Brétigny-sur-Orge Cedex, France

${ }^{*}$ Corresponding author:

Thierry Douki

ORCID: 0000-0002-5022-071X

Email : thierry.douki@cea.fr

Tel (33) 438783191

Fax (33) 438785090 


\section{Abstract}

Sulfur mustard, a chemical warfare agent known to be a vesicant of skin, readily diffuses in the blood stream and reaches internal organs. In the present study, we used the analog (2chloroethyl)-ethyl-sulfide (CEES) to provide novel data on the systemic diffusion of vesicants and on their ability to induce brain damage, which result in neurological disorders. $\mathrm{SKH}-1$ hairless mice were topically exposed to CEES and sacrificed at different time until 14 days after exposure. A plasma metabolomics study showed a strong systemic impact following a self-protection mechanism to alleviate the injury of CEES exposure. This result was confirmed by the quantification of specific biomarkers in plasma. Those were the conjugates of CEES with glutathione (GSH-CEES), cysteine (Cys-CEES) and N-acetyl-cysteine (NAC-CEES), as well as the guanine adduct (N7Gua-CEES). In brain, N7Gua-CEES could be detected both in DNA and in organ extracts. Similarly, GSH-CEES, Cys-CEES and NAC-CEES were present in the extracts until day14. Altogether, these results, based on novel exposure markers, confirm the ability of vesicants to induce internal damage following dermal exposure. The observation of alkylation damage to glutathione and DNA in brain provides an additional mechanism to the neurological insult of SM.

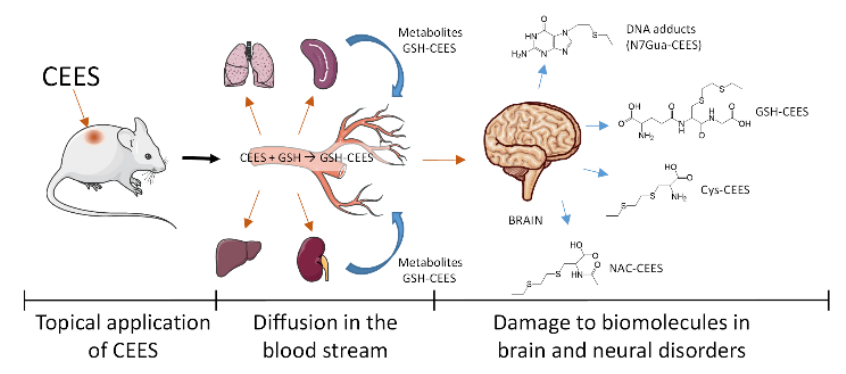

\section{Keywords}

2-Chloroethyl ethyl sulfide; biomarkers; plasma; brain. 


\section{Introduction}

Sulfur mustard (SM), or bis(2-chloroethyl) sulfide, is a chemical warfare agent used on a large scale during World War I (Romano et al., 2008), and on other battlefields until very recently (Sezigen and Kenar, 2020). In addition to these military concerns, SM is a threat for civilians that can be exposed to old ammunitions (Missiaen et al., 2010; Vanninen et al., 2020). More importantly, SM is thought to be a persistent threat by non-state actors, such as terrorist groups, because of its easy synthesis (Wattana and Bey, 2009). Neurological and psychological impacts have also been observed in exposed patients (Balali-Mood et al., 2005; Darchini-Maragheh et al., 2012; Rowell et al., 2009; Talabani et al., 2018; Thomsen et al., 1998), suggesting the occurrence of SM-mediated damage to the brain. In vitro experiments have confirmed than neuron were highly sensitive to SM (Lanks et al., 1975; Sawyer, 1999; Turnbull et al., 1973). Because handling of SM is strictly regulated and banned from most toxicology laboratories by the Organization for the Prohibition of Chemical Weapons (OPCW), other experimental works involved the analog 2-chloroethyl ethyl sulfide (CEES). Neurological effects of CEES confirmed those found for SM in vivo (Gadsden-Gray et al., 2012; GrosDesormeaux et al., 2018; Sharma et al., 2009).

One specific feature of SM and CEES is their ability to induce neuropathological disorders and brain damage after dermal exposure on small skin areas. This is partly explained by the fact that vesicant agents readily diffuse through skin, reach the blood stream and then diffuse to internal organs. Presence of SM in blood has been shown by using labeled compounds and quantifying the parent molecule as well as its degradation products (Chilcott et al., 2000; Cullumbine, 1947; Meng et al., 2019). Evidence was also provided by the detection of adducts to circulating proteins (Chen et al., 2019; Nie et al., 2011; Noort et al., 2008; Pantazides et al., 2019). The fact that SM then reaches internal organs, and in particular the brain, has been documented in human by post-mortem quantification of the toxic (Drasch et al., 1987). Evidence was also provided by the quantification of SM adducts in nuclear DNA (Batal et al., 2014; Batal et al., 2013; Brookes and Lawley, 1960; Fidder et al., 1994; Yue et al., 2015). Using the latter biomarker, brain was found to be a major target, possibly because of its large fat content. The present work, performed in a hairless mice model, aimed at further understanding the chain of events leading form dermal exposure by vesicant agents to brain damage. We wished to use CEES for which numerous other toxicological data are available. In particular, we reported that acute dermal exposure to CEES induced a significant increase in anxiety-like reactivity and an alteration of working memory (Gros-Desormeaux et al., 2018). We thus wanted to gather novel information on the diffusion step in blood and on the final damage to brain. 
These two goals first relied on the quantification of novel biomarkers. SM and CEES are both strong alkylating agents reacting with the nucleophilic sites present in biomolecules. This leads, as already mentioned, to the formation of DNA adducts. Another important target of SM is glutathione (GSH), the most abundant intracellular non-proteic thiol that plays major roles in antioxidant defense and detoxification. SM and CEES are electrophilic agents, which under their episulfonium form, exhibit strong alkylating properties. Like numerous electrophilic compounds, detoxification of SM and CEES occurs via conjugation to GSH. A widely proposed explanation to the toxicity of SM and CEES is their ability to deplete the GSH pool (Abel et al., 2011; Black et al., 1992a; Black et al., 1992b; Davison et al., 1961; Kinsey and Grant, 1947) and thereby inducing oxidative stress by reducing cellular antioxidant capacities. This effect is reflected by the modulation of a wide variety of markers of oxidative stress (Husain et al., 1996; Jafari, 2007; Mukhopadhyay et al., 2006; Paromov et al., 2007; Pohanka et al., 2011; Pohanka et al., 2013; Varmazyar et al., 2019). Evidence of the role of oxidative stress is confirmed by the ability of antioxidants at counteracting the toxic effects of SM (Mukherjee et al., 2009; Paromov et al., 2011; Paromov et al., 2008; Rappeneau et al., 2000; Shohrati et al., 2008; Tewari-Singh et al., 2011). These toxic effects impact glutathione content and are likely to affect the function of many organs exposed to vesicant agents and participate to their systemic effects. The conjugate of CEES to GSH (GSH-CEES) appear thus as an attractive effect biomarker that we quantified in plasma and brain. We also quantified two of its metabolites: the cysteine conjugate (Cys-CEES) and the final product of the mercapturate pathway $\mathrm{N}$ acetyl-cysteine conjugate (NAC-CEES). Data were also gathered on the DNA adduct 2-ethylthioethyl-N7-guanine (N7Gua-CEES), both in nuclei and in plasma.

As mentioned above, although previous studies have shown that toxicity of SM and CEES are associated with inflammation, oxidative stress, and DNA damages, the underlying biochemical mechanisms remain largely ignored. Therefore, we intended to reinforce current hypotheses and shed new light on CEES action mechanisms and effects through novel biomarkers that strongly. First, we targeted molecular biomarkers that like NAC-CEES had never been quantified nor investigated in brain. Second, we applied an extensive and state-of-the art untargeted metabolomics approach for getting deeper insight into underlying biochemical mechanisms. It should be stressed that few metabolomics studies have been published and involved NMR and/or GC-MS analysis of plasma samples from humans or rats exposed to SM (Liu et al., 2020; Nobakht et al., 2016; Nobakht et al., 2017). Although relevant, those studies provided partially overlapping results in terms of SM-altered metabolic pathways, probably because of the low number of metabolites monitored (less than 50). In the present work, we used an untargeted metabolomics approach based on liquid chromatography coupled to highresolution mass spectrometry that routinely enables the detection of about 200 metabolites in 
plasma samples (Boudah et al., 2014; Moreau et al., 2020; Tabone et al., 2021) for getting a more precise view of CEES-associated systemic damages. In addition to support the ability of vesicant at diffusing in blood and reaching brain, which is at the origin of neurological and psychological disorders, an aim of our study was also to validate in animals biomarkers of interest to develop for human exposure.

\section{Materials and methods}

\subsection{Animal experiment}

The protocol was validated by the ethic committee of Health Services of French Armed Forces. SKH-1 hairless mice were purchased from Charles River and used at 7 weeks. Mice were anesthetized by intraperitoneal injection of a mixture of ketamine $(90 \mathrm{mg} / \mathrm{kg})$ and xylazine (10 $\mathrm{mg} / \mathrm{kg}$ ). Under a fume hood, mice were then locally exposed through the skin to the vapors emitted by $10 \mu \mathrm{L}$ of neat CEES using cap method (screw cap for HPLC vial, PTFE septum and polypropylene cap, total volume $300 \mu$ ). Based on the known vapor pressure of $3.4 \mathrm{~mm} \mathrm{Hg}$ for CEES, it can be calculated that this exposure corresponds at the most to $0.4 \mathrm{mg} / \mathrm{kg}$ if the totality of the vapors is absorbed by the skin. Four sites on the mice back were exposed to CEES vapors during 30 minutes. After $4 \mathrm{~h}$, the skin was decontaminated by soap and water. To relieve pain induced by CEES, buprenorphine $(0.05 \mathrm{mg} / \mathrm{kg})$ was subcutaneously injected after skin decontamination and codeine was daily administrated in drinking water $(4 \mathrm{mg} / 100$ $\mathrm{mL}$ ). One, 3, 7 and 14 days after exposure, the animals $(n=16$ to 20$)$ were sacrificed by an injection of pentobarbital (150 mg/kg, ip route). The blood was collected by heart puncture. Plasma was separated by centrifugation (2000 g, 10 minutes, $4^{\circ} \mathrm{C}$ ) and samples were kept frozen until quantification of biomarkers. For this purpose, an aliquot fraction of $100 \mu \mathrm{l}$ was collected from each sample. The brain of the sacrificed animals was removed by surgery and kept frozen at $-80^{\circ} \mathrm{C}$ until use.

\subsection{Chemicals and enzymes}

Reduced L-glutathione (GSH), (2-chloroethyl)-ethyl sulfide (CEES) and L-cysteine (Cys) were purchased from Sigma Aldrich (Saint Quentin Falavier, France). N-Acetyl-L-cysteine (NAC) was purchased from Roche (Boehringen Mannheim) (Mannheim, Germany). 2'-Deoxyguanosine (dGuo) was purchased from Pharma Waldhof (Düsseldorf, Germany). Formic acid (LC-MS grade) was purchased from Thermo Fisher Scientific (Rockford, USA), acetonitrile (HPLC-MS grade) from VWR (Fontenay-sous-Bois, France), methanol (HPLC grade) and ammonium formate from Sigma Aldrich (Saint Quentin Falavier, France). 
Ribonuclease $\mathrm{T} 1$, ribonuclease $\mathrm{A}$, phosphodiesterase II, deoxyribonuclease II, alkaline phosphatase and nuclease P1 were obtained from Sigma. Protease was purchased from Qiagen and phosphodiesterase I from Worthington (Lakewood, NJ, USA). Isotopically labelled molecules Cys ${ }^{*}\left({ }^{13} \mathrm{C}_{3} 99 \%,{ }^{15} \mathrm{~N} 99 \%\right), \mathrm{NAC}^{*}\left({ }^{13} \mathrm{C}_{3} 97-99 \%{ }^{15} \mathrm{~N} 97-99 \%\right), \mathrm{GSH}^{*}\left({ }^{13} \mathrm{C}_{2} 98 \%{ }^{15} \mathrm{~N}\right.$ 96-99\%) and dGuo* $\left({ }^{15} \mathrm{~N}_{5}\right.$ 98\%) were purchased from Cambridge Isotope Laboratories (Andover, USA).

\subsection{Untargeted metabolomics experiments by liquid chromatography coupled to high-resolution mass spectrometry (LC-HRMS)}

The metabolomic study was performed according to a protocol previously developed and routinely used in our team, which relies on reverse phase chromatography, hydrophilic interaction liquid chromatography and high resolution mass spectrometry (Boudah et al., 2014; Moreau et al., 2020; Tabone et al., 2021). Two 50- $\mathrm{LL}$ aliquots were withdrawn from each plasma sample. Each aliquot was then mixed with $200 \mu \mathrm{L}$ of methanol and incubated on ice for $90 \mathrm{~min}$ to allow complete protein precipitation. After centrifugation, the supernatants were withdrawn and evaporated to dryness under a nitrogen stream. Finally, the extracts were resuspended in $100 \mu \mathrm{L}$ of starting mobile phases of the two chromatographic conditions. Quality control samples were obtained by pooling aliquots of each sample and these were injected every 10 samples throughout the analysis for further data normalization/standardization. Metabolic extracts were analyzed by LC-HRMS using an Ultimate 3000 chromatographic system (Thermo Fisher Scientific, Courtaboeuf, France) coupled to an Exactive mass spectrometer from Thermo Fisher Scientific fitted with an electrospray (ESI) source and operating in the positive and negative ion modes for metabolite separations on C18 and ZIC-pHILIC columns, respectively. LC-HRMS conditions were exactly those previously described by our group (Boudah et al., 2014). Data processing and statistical analysis were achieved using the Workflow4Metabolomics (W4M) platform (Giacomoni et al., 2015). Annotation of metabolite features was performed by using our spectral database first according to accurate measured masses and chromatographic retention times (Boudah et al., 2014). Metabolite identification was further confirmed for discriminant metabolites by running additional LC-MS/MS experiments using a Dionex Ultimate chromatographic system combined with a Q-Exactive mass spectrometer (Thermo Fisher Scientific, San Jose, CA, USA) under non-resonant collision-induced dissociation conditions using higher-energy C-trap dissociation (HCD). To be identified, metabolites had to match at least two orthogonal criteria (among accurate measured mass, retention time, and MS/MS spectrum) to those of an authentic chemical standard analyzed under the same analytical conditions, as proposed by the Metabolomics Standards Initiative (Sumner et al., 2007). 


\subsection{Brain sample preparation}

\subsubsection{DNA extraction from brain}

DNA extraction from the brain was achieved as previously described (Ravanat et al., 2002). Then, DNA was hydrolyzed in two steps as previously developed in the group (Douki et al., 2004). Each step involved a specific enzymatic cocktail: nuclease P1, phosphodiesterase II and DNase II at pH 6 for the first; phosphodiesterase I and alkaline phosphatase at $\mathrm{pH} 8$ for the second. Each step was carried out at $37^{\circ} \mathrm{C}$ for $2 \mathrm{~h}$. The samples were then left at $90^{\circ} \mathrm{C}$ for 20 min in a heating block in order to depurinate DNA adducts. The final samples thus contain normal DNA bases under the form of nucleosides, which are quantified by a UV detector placed before the inlet of the mass spectrometer, and adducts as modified bases quantified by mass spectrometry. Samples were filtered prior to analysis at $0.2 \mu \mathrm{m}$ on filtration column (VWR) centrifuged at $8000 \mathrm{xg}$ for $5 \mathrm{~min}$.

\subsubsection{Metabolites extraction from brain}

The used protocol is based on the work of Malik et al (Malik et al., 2018). In brief, samples were thawed in an ice bath and spiked with isotopically labelled internal standards. A stainless steel bead and $300 \mu \mathrm{L}$ of a cold methanol:chloroform solution were added to each brain sample. Samples were then homogenised by shaking at $25 \mathrm{~Hz}$ for $4 \mathrm{~min}$ in a TissueLyser (Qiagen). Then, samples are placed back on ice. Then, $100 \mu \mathrm{L}$ of cold water was added before vortexing. Sample were then centrifuged at $18,787 \mathrm{xg}$ for $7 \mathrm{~min}$ at $4{ }^{\circ} \mathrm{C}$. The upper layer, which contains the polar metabolites of interest, was carefully collected and placed in a new tube to be dried in a SPD111V speed vac (Thermo Scientific). The resulting residue was dissolved in $50 \mu \mathrm{l}$ of water and filtered at $0.2 \mu \mathrm{m}$ on filtration column (VWR) centrifuged at $8000 \mathrm{xg}$ for $5 \mathrm{~min}$.

\subsection{On-line solid phase extraction of plasma}

An improved version of the previously reported assay for plasma samples (Roser et al., 2021) was used. Classical solid phase extraction was replaced by on line SPE. Prior to analysis, the samples (90 $\mu \mathrm{L}$ of plasma) were spiked with internal standards $(10 \mu \mathrm{L}, 0.2 \mu \mathrm{M})$ and loaded onto a $0.2 \mu \mathrm{m}$ filtration column (VWR). Then, they were centrifuged at $8000 \mathrm{xg}$ for $5 \mathrm{~min}$. The filtrate was collected and loaded onto a $30 \mathrm{kDa}$ Nanosep ${ }^{\circledR}$ tube. This second filtration step involved a centrifugation for $30 \mathrm{~min}$ at $8000 \mathrm{x}$ g. Additional sample clean-up was performed directly on-line within the UHPLC system. The samples were injected (50 $\mu \mathrm{L})$ first in a Macherey-Nagel Nucleodur® PFP column (50 mm x $2.0 \mathrm{~mm}$ ID, $5 \mu \mathrm{m}$ particle size) used as 
an on-line SPE column. Mobile phase A consisted of $5 \mathrm{mM}$ ammonium formate (AmF) in MilliQ water and mobile phase B was HPLC-LC/MS grade methanol with $5 \mathrm{mM} \mathrm{AmF.} \mathrm{Samples} \mathrm{were}$ cleaned by a gradient from 0 to $50 \%$ of $B$ in 1 minute. The flow rate was set to $350 \mu \mathrm{L} / \mathrm{min}$, the column temperature maintained at $50^{\circ} \mathrm{C}$ and the sample storage compartment set to $15^{\circ} \mathrm{C}$. After that, samples are injected by backflush into the analytical column.

\subsection{UHPLC-MS/MS Quantification of the biomarkers}

Quantification by ultra high performance liquid chromatography associates with tandem mass spectrometry (UHPLC-MS/MS) of GSH-CEES, Cys-CEES, NAC-CEES and N7Gua-CEES was carried out using a recently described approach (Roser et al., 2021). Chromatographic separations were carried out on an ExionLC system (SCIEX, Framingham, MA) equipped. The on-line SPE part consisted in an autosampler, two pumps and a $2 \times 50 \mathrm{~mm}$ ID pentafluorophenyl column ( $5 \mu \mathrm{m}$ particle size, Nucleodur PFP, Macherey-Nagel). The analytical part involved two pumps, a heated column compartment and the detectors. Analytical separation was performed using a Macherey-Nagel Nucleodur® C18 column (100 mm x $2.0 \mathrm{~mm}$ ID, $1.8 \mu \mathrm{m}$ particle size). Connection between the on-line SPE and the analytical sub-units was controlled by a 6 -ways valve. The mobile phase consisted in a gradient of $2 \mathrm{mM} \mathrm{AmF}$ and LC/MS grade acetonitrile. Detection was afforded by a SCIEX QTRAP® 6500+ triple quadrupolar mass spectrometer (Framingham, MA) equipped with an lon Drive ${ }^{\mathrm{TM}}$ Turbo $\mathrm{V}$ source operated in positive ionization mode. Data were collected in multiple reaction monitoring (MRM) scan mode using previously reported transitions (Roser et al., 2021). Quantification of N7Gua-CEES in DNA also involved on-line UV quantification on unmodified nucleosides in order to determine the amount of analyzed DNA.

\subsection{Statistical analysis}

Statistical analysis were performed on pools of replicates originating from different animals. Data were statistically analyzed in GraphPad PRISM using one-way ANOVA followed by the non-parametric Kruskal-Wallis test for multiple comparisons. Univariate and multivariate analyses of metabolomics data were also performed using the W4M platform (Giacomoni et al., 2015), while the online MetaboAnalyst platform was used for heatmap generation and metabolic pathway enrichment (Chong et al., 2018). 


\section{Results}

\subsection{Untargeted metabolomics analysis of plasma samples from mice exposed to} CEES

Metabolomics analyses of mouse plasma samples were performed using two complementary LC-HRMS platforms involving reversed-phase chromatography [C18(+)]) and Hydrophilic Interaction Liquid Chromatography [HILIC(-)], for the analysis of hydrophobic and polar metabolites in the positive and the negative ionization modes, respectively. Under these conditions, 57 metabolite features from the $\mathrm{C} 18(+)$ and 165 from the HILIC(-) analysis matched the accurate masses and retention times of the metabolites included in our chemical database, thus yielding 199 unique annotated metabolites in total. Although principal component analysis (PCA) did not reveal any obvious differences between the 4 post-exposure times (data not shown), a clustered analysis heatmap was generated to group the related metabolites (top 50 ones by ANOVA p-values), and highlighted a time-dependent evolution of metabolite patterns through the 14 days of exposure (Fig.1A). A small portion of the top 50 metabolites was more abundant at day 1 while most of them accumulated at day 3 and plateauing afterwards, before returning to "baseline" levels at day 14 (i.e. similar profile than non-exposed mice). The metabolic profile at day 1 post-exposure proved significantly different from those at days 3 and 7 (Fig. 1A). Tables S1, S2 and S3 present the metabolites with p-values $<0.05$ and fold changes $>1.5$ when comparing non-exposed mice to day 1 , day 1 to day 3 , and day 3 to day 7 post-exposure, respectively. Differences between day 1 and day 3 were the more striking and thus the more precisely studied (Table S2). Under these conditions, 65 and 26 statistically different metabolites were retrieved from HILIC(-) and C18(+) datasets, respectively (Table S1). Metabolic pathway analysis showed that arginine and proline metabolism, arginine biosynthesis, histidine metabolism, purine metabolism and primary bile acid synthesis were among the most affected metabolic pathways (Fig. S1). Figure 2 presents the post-exposure evolution of some key metabolites showing markedly increased or decreased concentration levels between day 1 and day 3, also by comparison to other time points post-exposure and non-exposed animals.

$$
\begin{aligned}
& \text { < Figure 1 > } \\
& \text { < Figure 2 > }
\end{aligned}
$$

\subsection{Targeted CEES biomarkers in blood plasma}

Analysis of plasma samples benefited from an efficient and reproducible on-line SPE approach (Kuklenyik et al., 2011) that was used to improve our UHPLC-MS/MS method for CEES 
biomarkers (Roser et al., 2021). None of the analytes could be detected in the plasma of untreated animals. The time-course variation of the level of N7Gua-CEES in plasma exhibited a fast decrease following a maximal concentration found at the first investigated time of 1 day post exposure (Table 1). At day 14, the level of adduct was low but still above the limit of detection (LOD). GSH-CEES was detected in most samples but its level was always closed to the LOD and hardly varied with time. In contrast, Cys-CEES and NAC-CEES were found to be present in large concentrations. Their amounts were maximal at day 1 and then readily decreased. The rate of this second phase was slightly lower for Cys-CEES than NAC-CEES. Detection of NAC-CEES was yet more sensitive and its concentration after 14 days was still 12 times higher than its limit of detection (LOD).

$<$ Table $1>$

\subsection{Quantification of CEES biomarkers in brain}

The molecular biomarkers were then quantified in the brain of exposed mice sacrificed just before the exposure or 1, 3, 7, and 14 days after topical application of CEES. A first analyte of interest was N7Gua-CEES. Its occurrence was first measured in the nuclear DNA extracted from the whole brain (Fig. 3a). No trace of adduct was found before exposure. Over time, the amount of N7Gua-CEES was maximal at day 1 and day 3 . The difference between the two values was not statistically significant. After this peak, the value decreases. N7Gua-CEES is though still detectable after 14 days (18.0 \pm 6.7 adducts per $10^{6}$ bases) with a sensitivity corresponding to 28 times the value of its LOD. N7Gua-CEES was also detected in the organ's extracts prepared by homogenisation and solvents extraction (Fig. 3a). The N7Gua-CEES concentration was highest at day 1 and then decreased to $10 \%$ of this value at day 14 .

$$
<\text { Figure } 3>
$$

The concentrations of the three CEES conjugates GSH-CEES, Cys-CEES and NAC-CEES arising from the mercapturate pathway were also determined in the brain extracts (Fig. $3 b$ ). They were found to be in the same range at day 1 . This value was the highest of the four investigated days for GSH-CEES and NAC-CEES. A higher concentration was found for CysCEES at day 3 but the difference was not statistically different from day 1. A concentration decrease was then observed for the three biomarkers. It was faster for GSH-CEES. Because this analyte exhibited the lowest sensitivity in the analytical method, it was below the limit of quantification in all samples at day 3 and in a large fraction of those at day 7 and 14. In contrast to GSH-CEES, the concentrations of Cys-CEES and NAC-CEES decreased slowly over the 2 weeks of follow-up. They were still detectable at day 14, with a good sensitivity for NAC-CEES 
corresponding to a factor of 9 with respect to the LOD. The quantification of Cys-CEES at day 14 was hampered by the presence of traces of interfering peaks.

\section{Discussion}

In addition to directly observable effects on skin, eyes and lungs, SM exhibits neurological and psychological effects (Balali-Mood and Hefazi, 2006; Isono et al., 2018; Sharma et al., 2009). However, most of the related observational studies were performed on veterans of Iran-Irak war (1980-88), many years after their initial exposure. It is thus not possible to distinguish between the toxic effects of SM itself on the one hand, and war stress on the other hand. Similarly, two non-exclusive origins for the neurological and pathological effects of SM and vesicants can be proposed. The first is a response to the exposure stress while the second is a diffusion of SM and CEES through the exposed skin followed by direct and indirect diffusion to the brain with resulting local effects. Thus, our group carried out an in vivo study on hairless SKH-1 mice topically exposed to CEES, the SM analog used in the present study, in order to clarify the origin of the behavioral effects observed in humans (Gros-Desormeaux et al., 2018). In this study, CEES-treated mice were compared with a control group burnt with hydrochloric acid. Our results evidenced that the anxiety and long-lasting working memory impairments observed in mice were due to the vesicant agent itself, and not to the burn effect or to the war stress. This conclusion is actually strongly supported by the observation that brain was one of the organs exhibiting the largest concentration of SM in a post-mortem study on an exposed Iranian soldier (Drasch et al., 1987).

Explanation to the effects of vesicants in brain can be found in a few studies showing the induction of apoptosis and oxidative stress in the brain of mice chronically exposed to SM by percutaneous route (Sharma et al., 2009). Histological and immunohistochemical analyses of brains of guinea pigs exposed to CEES by intratracheal injection showed a loss of neural cells in all brain regions, likely resulting from an activation of microglial cells by $\alpha$-synuclein (Gadsden-Gray et al., 2012). In spite of these biochemical modifications, no major tissue damage was reported in the brain of rats topically exposed to large doses of SM (up to 45 $\mathrm{mg} / \mathrm{kg}$ ) with the exception of haemorrhage (Yue et al., 2015). These results unambiguously show the presence of SM or CEES in brain of treated animals. However, they do not provide quantitative information on the kinetic of diffusion from the exposed site or on the distribution between internal organs. This is the reason why quantification of exposure and effect biomarkers represent an interesting complementary approach. Evidence that SM and its analogs diffuse in the blood stream is shown by the detection of its degradation products (Li et 
al., 2013; Manandhar et al., 2018; Qi et al., 2016) and of protein adducts in plasma (John et al., 2019; Liu et al., 2015; Noort et al., 2008; Xu et al., 2014). SM or CEES may also react in plasma with small molecules such as glutathione, which leads to the presence of conjugates in blood. The GSH conjugates may also be produced within cells by detoxification enzymes glutathione-S-transferases (Sheehan et al., 2001) and further excreted into biological fluids. Quantification of such biomarkers in plasma would thus reflect a systemic effect of vesicant agents because their presence in blood would originate from all organs.

Therefore, our result confirm both the diffusion of CEES from skin to blood and the subsequent exposure of internal organs. We obtained data not only on GSH-CEES, but also on Cys-CEES and NAC-CEES, two metabolites of GSH-CEES resulting from the action of several enzymes (Hanna and Anders, 2019; Wu et al., 2004). We recently developed a method for their quantification and validated their biological relevance (Roser et al., 2021). Using an improved version of this approach, we detected large amounts of GSH-CEES metabolites in the plasma of the CEES-treated mice in the following decreasing order of concentration: Cys-CEES > NAC-CEES >> GSH-CEES. The observation of a very low concentration in GSH-CEES is in agreement with well identified features of the mercapturate pathway involved in the detoxification of electrophilic species such as CEES or SM. GSH-CEES is converted into CysGly-CEES and Cys-CEES through the consecutive actions of membrane-bound-enzymes $\gamma$ glutamyl-transferase (GGT) and dipeptidase or aminopeptidase-M, respectively (GonçalvesDias et al., 2019; Hanna and Anders, 2019). The last step of the mercapturate pathway involves the entrance of Cys-S-conjugates into the renal tubular cells and hepatocytes via various transporters including organic anion transport polypeptides and cystine/cysteine transporters (Griffith, 1981; Hanigan, 1998; Hughey et al., 1978). There, the Cys-S-conjugates are acetylated by the N-acetyl-transferase NAT8 (Chambers et al., 2010).

Another interesting observation was the confirmation of the presence of the DNA adduct N7Gua-CEES in plasma samples (Roser et al., 2021). This modified nucleic acid base may have several origins. The most likely is the depurination from DNA, which a characteristic of N7-alkylated guanine adducts (Boysen et al., 2009). Likewise, N7Gua-CEES could originate from RNA and the pool of nucleotides. These results on N7Gua-CEES are in line with those obtained with SM (Zhang et al., 2014) and further validate the use of CEES as a relevant analog of SM. In terms of time course, all the detected biomarkers were at their maximal plasma concentration at day 1 and then rapidly decreased. At day 14, the respective level of NAC-CEES and Cys-CEES was 9 and $20 \%$ of that at day 1, while the corresponding value was $1 \%$ for N7Gua-CEES. These data confirm results from the literature that SM readily diffuses into blood after dermal exposure (Nagy et al., 1946). These data also reflect the formation of CEES-mediated damage to biomolecules all-over the mouse organism. 
To further study the latter point, we performed an untargeted metabolomics study that enabled the detection of almost 200 unique metabolites in the plasma of exposed mice. These results revealed a systemic alteration of metabolism, involving various metabolic pathways (arginine and proline metabolism, arginine biosynthesis, histidine metabolism, purine metabolism and primary bile acid synthesis,...), with the most striking differences occurring between days 1 and 3 post-exposure (Fig. 1, Fig. S1). Noteworthy is the fact that a few particular metabolites accumulate at day 1 , which might reflect a self-protection effect to alleviate the injury of CEES exposure and/or inflammatory response. Among those metabolites, arginine and histidinerelated metabolites (e.g., urocanic acid, anserine, carnosine) are of special interest. Arginine analogues have been demonstrated to exhibit protective characteristics against SM poisoning (Rappeneau et al., 2000), while SM analogues were demonstrated to form covalent adducts with histidine and histidine-containing peptides (Hemme et al., 2021). Carnosine, a dipeptide composed of $\beta$-alanine and L-histidine, and its methylated analog anserine are major constituents within mammalian skeletal muscle that play key roles in muscle contraction/excitation as intracellular buffer and antioxidant (Boldyrev et al., 2013). The antioxidant activity of carnosine and related peptides has been demonstrated as well as their ability to prevent the formation of advanced lipoxidation end-products and advanced glycoxidation end-products, for instance by forming adducts with reactive lipid oxidation products (Boldyrev et al., 2013). Urocanic acid, existing as trans and cis isomers, is a breakdown (deamination) product of histidine produced by the catalytic action of histidine ammonia-lyase (Walterscheid et al., 2006). In the epidermis, it accumulates and may be both a UV protectant and an immunoregulator. Trans-urocanic acid upon UV light absorption is isomerized to the cis-isomer in the stratum corneum. Cis-urocanic acid can suppress cellular immunity in mice (Hug et al., 1998), and has been identified as a serotonin receptor ligand (Walterscheid et al., 2006). In addition to potential anti-inflammatory effects, recent data demonstrate that urocanic acid also promotes glutamate biosynthesis and release in various brain regions which can impact recognition memory and motor learning in mice (Zhu et al., 2018).

Beside, we also observed accumulation of hydroxyglutaric acid and glutaconic acid in the plasma of exposed mice at day 1 . This is a feature commonly observed in glutaric aciduria type I caused by inherited deficiency of glutaryl-CoA dehydrogenase which is involved in the catabolic pathways of L-lysine, L-hydroxylysine and L-tryptophan (Kolker et al., 2011). In this case, high levels of those organic acids can cause damage to the brain (and also other organs), but particularly the basal ganglia, which are regions that help regulate movement (Kolker et al., 2011). Such organic acids can be detoxified by carnitine (Strauss et al., 2020). Thus, these 
observations might also be linked with the modulated levels of carnitine species observed upon CEES exposure (Table S1). Last, many other metabolites present at low levels at day 1 proved up-regulated at day 3 . Among those are metabolites belonging to purine and pyrimidine metabolism, pentose phosphate pathway, beta-oxidation, etc..., which underlines the broad systemic effect caused by CEES poisoning. Also the strong dysregulation of bile acids (taurocholic and taurodeoxycholic acid) can indicate liver dysfunction and/or an impact on gut microbiota (Łuczykowski et al., 2021). Of note, untargeted metabolomics does not detect CEES adducts due to insufficient detection sensitivity.

Overall, our metabolomics approach provided an unprecedented view on the impact of CEES on mouse metabolism. Metabolite profiling until 14 days post-exposure highlighted a two-wave organism response to CEES poisoning. An early phase response at day 1 that might reflect a self-protection effect through the accumulation of anti-inflammatory nucleophilic compounds precedes a more systematic effect from day 3 involving many different metabolic pathways.

Having confirmed the systemic diffusion of CEES in topically exposed $\mathrm{SKH}-1$ mice, we then focussed on the brain. First, in agreement with previous works on SM (Batal et al., 2014; Yue et al., 2015), we detected large amounts of N7Gua-CEES adducts in the nuclear DNA of this organ. Interestingly, the same adduct was detected in brain extracts aimed at isolating metabolites. Like in plasma, N7Gua-CEES found in these samples likely results from depurination of DNA, RNA or nucleotide pool. The formation DNA adducts is an interesting observation that could partly explain some of the neurological effects of vesicant agents. Indeed, the formation of large amounts of DNA damage has been proposed as one of the mechanisms leading to cell death (Debiak et al., 2009; Kehe et al., 2009; Papirmeister et al., 1985).

We also observed that brain extracts contained the three investigated metabolites resulting from the reaction of CEES with GSH. Like in plasma, the parent molecule in this pathway, GSH-CEES, was present in the lowest amount after the first day of exposure. This observation is reminiscent of those made in in vitro experiment using CEES on human skin cells and skin explants (Roser et al., 2021). In contrast, Cys-CEES was the most frequent and more persistent. This clearly illustrates the efficiency of the metabolism of GSH conjugates that aims at maintaining a sufficient cellular content in this essential tripeptide (Forman et al., 2009; Griffith, 1999; Wu et al., 2004). NAC-CEES was also unambiguously detected, in amounts representing roughly $75 \%$ of that of Cys-CEES. This is slightly unexpected since $\mathrm{N}$-acetyltransferases are believed to be mostly renal and hepatic enzymes (Chambers et al., 2010; Hinchman et al., 1998). Evidence from the literature yet suggest that brain also expresses $N$-acetyltransferases (Hanna and Anders, 2019). Accordingly, Miller et al. (Miller et 
al., 1995) observed the formation of a mercapturic acid derivative in all brain regions. More recently, the mercapturate pathway activity was also detected in the brain although with a lower efficiency than in liver (Sidell et al., 2003). An additional explanation to the observation of large amounts of NAC-CEES in brain is that this organ receives $15-20 \%$ of the cardiac output, attesting to the high vascular demand of the brain. Thus, a part of the detected NAC-CEES could originate from the blood where it is present in large concentration as shown by the measurements in the plasma. A last observation regarding biomarkers in brain is that their decreases more slowly than in plasma, with the exception of GSH-CEES. This may be explained by a longer persistence of CEES in brain than in the rest of the organism because of a larger fat content and the formation of a reservoir compartment.

\section{Conclusion}

The present work, based on novel experimental approaches involving untargeted metabolomics and quantification of recently validated specific molecular biomarkers, provides observations relevant to a better understanding of the occurrence of neurological and psychological disorders after exposure to vesicant agents like SM. Our work confirms that, following diffusion through skin, vesicant agents enter the blood stream and cross the hematoencephalic barrier. Then, the compounds enter the brain and induce a series of damaging processes. Our data reveals that the formation and clearance of the studied biomarkers spreads over two weeks, reflecting the persistence of the chemical in the brain. Our work also shed some light on the systemic effects of CEES, potential underlying biochemical mechanisms and especially the interest of some biomarkers. NAC-CEES and Gua-CEES were found to be those detected with the best LOD in our UHPLC-MS/MS and to persist for more than two weeks in brain and plasma. The last point is important for applications of the UHPLC-MS/MS assay to human.

\section{Acknowledgements}

This work was supported by the "Agence de I'Innovation de Défense" (French Defense Ministry) and the "NRBC" program of the French Alternative Energies and Atomic Energy Commission.

\section{Conflict of Interest}

The authors declare that they have no conflict of interest. 


\section{References}

Abel, E.L., Bubel, J.D., Simper, M.S., Powell, L., McClellan, S.A., Andreeff, M., MacLeod, M.C., DiGiovanni, J., 2011. Protection against 2-chloroethyl ethyl sulfide (CEES) - induced cytotoxicity in human keratinocytes by an inducer of the glutathione detoxification pathway. Toxicol. Appl. Pharmacol 255, 176-183.

Balali-Mood, M., Hefazi, M., 2006. Comparison of early and late toxic effects of sulfur mustard in Iranian veterans. Basic Clin. Pharmacol. Toxicol. 99, 273-282.

Balali-Mood, M., Hefazi, M., Mahmoudi, M., Jalali, E., Attaran, D., Maleki, M., Razavi, M.E., Zare, G., Tabatabaee, A., Jaafari, M.R., 2005. Long-term complications of sulphur mustard poisoning in severely intoxicated Iranian veterans. Fundam. Clin. Pharmacol. 19, 713-721.

Batal, M., Boudry, I., Mouret, S., Clery-Barraud, C., Wartelle, J., Berard, I., Douki, T., 2014. DNA damage in internal organs after cutaneous exposure to sulphur mustard. Toxicol. Appl. Pharmacol 278, 39-44.

Batal, M., Boudry, I., Mouret, S., Wartelle, J., Emorine, S., Bertoni, M., Berard, I., CleryBarraud, C., Douki, T., 2013. Temporal and spatial features of the formation of DNA adducts in sulfur mustard-exposed skin. Toxicol. Appl. Pharmacol 273, 644-650.

Black, R.M., Brewster, K., Clarke, R.J., Hambrook, J.L., Harrison, J.M., Howells, D.J., 1992a. Biological fate of sulphur mustard, 1,1'-thiobis(2-chloroethane): isolation and identification of urinary metabolites following intraperitoneal administration to rat. Xenobiotica 22, 405-418.

Black, R.M., Hambrook, J.L., Howells, D.J., Read, R.W., 1992b. Biological fate of sulfur mustard, 1,1'-thiobis(2-chloroethane). Urinary excretion profiles of hydrolysis products and beta-lyase metabolites of sulfur mustard after cutaneous application in rats. J Anal Toxicol 16, 79-84.

Boldyrev, A.A., Aldini, G., Derave, W., 2013. Physiology and pathophysiology of carnosine. Physiol Rev 93, 1803-1845.

Boudah, S., Olivier, M.F., Aros-Calt, S., Oliveira, L., Fenaille, F., Tabet, J.C., Junot, C., 2014. Annotation of the human serum metabolome by coupling three liquid chromatography methods to high-resolution mass spectrometry. J Chromatogr B Analyt Technol Biomed Life Sci 966, 34-47.

Boysen, G., Pachkowski, B.F., Nakamura, J., Swenberg, J.A., 2009. The formation and biological significance of N7-guanine adducts. Mutat Res 678, 76-94.

Brookes, P., Lawley, P.D., 1960. The reaction of mustard gas with nucleic acids in vitro and in vivo. Biochem. J. 77, 478-484.

Chambers, J.C., Zhang, W., Lord, G.M., van der Harst, P., Lawlor, D.A., Sehmi, J.S., Gale, D.P., Wass, M.N., Ahmadi, K.R., Bakker, S.J.L., Beckmann, J., Bilo, H.J.G., Bochud, M., Brown, M.J., Caulfield, M.J., Connell, J.M.C., Cook, H.T., Cotlarciuc, I., Smith, G.D., de Silva, R., Deng, G., Devuyst, O., Dikkeschei, L.D., Dimkovic, N., Dockrell, M., Dominiczak, A., Ebrahim, S., Eggermann, T., Farrall, M., Ferrucci, L., Floege, J., Forouhi, N.G., Gansevoort, R.T., Han, X., Hedblad, B., van der Heide, J.J.H., Hepkema, B.G., Hernandez-Fuentes, M., Hypponen, E., Johnson, T., de Jong, P.E., Kleefstra, N., Lagou, V., Lapsley, M., Li, Y., Loos, R.J.F., Luan, J.a., Luttropp, K., Maréchal, C., Melander, O., Munroe, P.B., Nordfors, L., Parsa, A., Peltonen, L., Penninx, B.W., Perucha, E., Pouta, A., Prokopenko, I., Roderick, P.J., Ruokonen, A., Samani, N.J., Sanna, S., Schalling, M., Schlessinger, D., Schlieper, G., Seelen, M.A.J., Shuldiner, A.R., Sjögren, M., Smit, J.H., Snieder, H., Soranzo, N., Spector, T.D., Stenvinkel, P., Sternberg, M.J.E., Swaminathan, R., Tanaka, T., Ubink-Veltmaat, L.J., Uda, M., Vollenweider, P., Wallace, C., Waterworth, D., Zerres, K., Waeber, G., Wareham, N.J., Maxwell, P.H., McCarthy, M.I., Jarvelin, M.-R., Mooser, V., Abecasis, G.R., Lightstone, L., 
Scott, J., Navis, G., Elliott, P., Kooner, J.S., 2010. Genetic loci influencing kidney function and chronic kidney disease. Nature Genetics 42, 373-375.

Chen, B., Yu, H.-L., Liu, S.-L., Liu, C.-C., Liang, L.-H., Li, X.-H., Li, X.-S., Wu, J.-N., Yang, Y., 2019. A sensitive quantification approach for detection of HETE-CP adduct after benzyl chloroformate derivatization using ultra-high-pressure liquid chromatography tandem mass spectrometry. Anal. Bioanal. Chem. 411, 3405-3415.

Chilcott, R.P., Jenner, J., Carrick, W., Hotchkiss, S.A.M., Rice, P., 2000. Human skin absorption of bis-2-(chloroethyl)sulphide (sulphur mustard) in vitro. J. Appl. Toxicol. 20, 349355.

Chong, J., Soufan, O., Li, C., Caraus, I., Li, S., Bourque, G., Wishart, D.S., Xia, J., 2018. MetaboAnalyst 4.0: towards more transparent and integrative metabolomics analysis. Nucleic Acids Res 46, W486-W494.

Cullumbine, H., 1947. Medical aspects of mustard gas poisoning. Nature 159, 151-153.

Darchini-Maragheh, E., Nemati-Karimooy, H., Hasanabadi, H., Balali-Mood, M., 2012. Delayed Neurological Complications of Sulphur Mustard and Tabun Poisoning in 43 Iranian Veterans. Basic Clin. Pharmacol. Toxicol. 111, 426-432.

Davison, C., Rozman, R.S., Smith, P.K., 1961. Metabolism of bis-beta-chloroethyl sulfide (sulfur mustard gas). Biochem Pharmacol 7, 65-74.

Debiak, M., Kehe, K., Burkle, A., 2009. Role of poly(ADP-ribose) polymerase in sulfur mustard toxicity. Toxicology 263, 20-25.

Douki, T., Odin, F., Caillat, S., Favier, A., Cadet, J., 2004. Predominance of the 1,N-2-propano 2 '-deoxyguanosine adduct among 4-hydroxy-2-nonenal-induced DNA lesions. Free Rad. Biol. Med. 37, 62-70.

Drasch, G., Kretschmer, E., Kauert, G., von Meyer, L., 1987. Concentrations of mustard gas [bis(2-chloroethyl)sulfide] in the tissues of a victim of a vesicant exposure. J Forensic Sci 32, 1788-1793.

Fidder, A., Moes, G.W.H., Scheffer, A.G., Vanderschans, G.P., Baan, R.A., Dejong, L.P.A., Benschop, H.P., 1994. Synthesis, characterization and quantitation of the major adducts formed between sulfur mustard and DNA of calf thymus and human blood. Chem. Res. Toxicol. 7, 199-204.

Forman, H.J., Zhang, H.Q., Rinna, A., 2009. Glutathione: overview of its protective roles, measurement, and biosynthesis. Mol. Asp. Med. 30, 1-12.

Gadsden-Gray, J., Mukherjee, S., Ogunkua, O., Das, S.K., 2012. Induction of neuronal damage in guinea pig brain by intratracheal infusion of 2-chloroethyl ethyl sulfide, a mustard gas analog. J. Biochem. Molec. Toxicol. 26, 23-30.

Giacomoni, F., Le Corguille, G., Monsoor, M., Landi, M., Pericard, P., Petera, M., Duperier, C., Tremblay-Franco, M., Martin, J.F., Jacob, D., Goulitquer, S., Thevenot, E.A., Caron, C., 2015. Workflow4Metabolomics: a collaborative research infrastructure for computational metabolomics. Bioinformatics 31, 1493-1495.

Gonçalves-Dias, C., Morello, J., Correia, M.J., Coelho, Nuno R., Antunes, Alexandra M.M., Macedo, Maria P., Monteiro, Emília C., Soto, K., Pereira, Sofia A., 2019. Mercapturate Pathway in the Tubulocentric Perspective of Diabetic Kidney Disease. Nephron 143, 17-23.

Griffith, O.W., 1981. The Role of Glutathione Turnover in the Apparent Renal Secretioonf Cystine. J. Biol. Chem. 256, 12263-12268.

Griffith, O.W., 1999. Biologic and pharmacologic regulation of mammalian glutathione synthesis. Free Rad. Biol. Med. 27, 922-935.

Gros-Desormeaux, F., Beracochea, D., Dorandeu, F., Pierard, C., 2018. Cognitive and emotional impairments after cutaneous intoxication by CEES (a sulfur mustard analog) in mice. Toxicol. Lett. 293, 73-76. 
Hanigan, M.H., 1998. y-Glutamyl transpeptidase, a glutathionase: Its expression and function in carcinogenesis. Chem.-Biol. Interact. 111-112, 333 - 342.

Hanna, P.E., Anders, M.W., 2019. The mercapturic acid pathway. Crit. Rev. Toxicol. 49, 819929.

Hemme, M., Fidder, A., van der Riet-van Oeveren, D., van der Schans, M.J., Noort, D., 2021. Mass spectrometric analysis of adducts of sulfur mustard analogues to human plasma proteins: approach towards chemical provenancing in biomedical samples. Anal Bioanal Chem 413, 4023-4036.

Hinchman, C.A., Rebbeor, J.F., Ballatori, N., 1998. Efficient hepatic uptake and concentrative biliary excretion of a mercapturic acid. Am. J. Physiol. - Gastrointest. Liver Physiol. 275, G612G619.

Hug, D.H., Hunter, J.K., Dunkerson, D.D., 1998. The potential role for urocanic acid and sunlight in the immune suppression associated with protein malnutrition. $J$ Photochem Photobiol B 44, 117-123.

Hughey, R.P., Rankin, B.B., Elce, J.S., Curthoys, N.P., 1978. Specificity of a particulate rat renal peptidase and its localization along with other enzymes of mercapturic acid synthesis. Arch. Biochem. Biopphys. 186, 211-217.

Husain, K., Dube, S.N., Sugendran, K., Singh, R., DasGupta, S., Somani, S.M., 1996. Effect of topically applied sulphur mustard on antioxidant enzymes in blood cells and body tissues of rats. J. Appl. Toxicol. 16, 245-248.

Isono, O., Kituda, A., Fujii, M., Yoshinaka, T., Nakagawa, G., Suzuki, Y., 2018. Long-term neurological and neuropsychological complications of sulfur mustard and Lewisite mixture poisoning in Chinese victims exposed to chemical warfare agents abandoned at the end of WWII. Toxicol. Lett. 293, 9-15.

Jafari, M., 2007. Dose- and time-dependent effects of sulfur mustard on antioxidant system in liver and brain of rat. Toxicology 231, 30-39.

John, H., Koller, M., Worek, F., Thiermann, H., Siegert, M., 2019. Forensic evidence of sulfur mustard exposure in real cases of human poisoning by detection of diverse albumin-derived protein adducts. Arch. Toxicol. 93, 1881-1891.

Kehe, K., Thiermann, H., Balszuweit, F., Eyer, F., Steinritz, D., Zilker, T., 2009. Acute effects of sulfur mustard injury-Munich experiences. Toxicology 263, 3-8.

Kinsey, V.E., Grant, W.M., 1947. Action of mustard gas and other poisons on yeast cells: study of the relationship between inhibition of carbohydrate metabolism and inhibition of growth by various poisons, and effects of other toxic agents on yeast. J Cell Physiol 30, 31-42.

Kolker, S., Christensen, E., Leonard, J.V., Greenberg, C.R., Boneh, A., Burlina, A.B., Burlina, A.P., Dixon, M., Duran, M., Garcia Cazorla, A., Goodman, S.I., Koeller, D.M., Kyllerman, M., Muhlhausen, C., Muller, E., Okun, J.G., Wilcken, B., Hoffmann, G.F., Burgard, P., 2011. Diagnosis and management of glutaric aciduria type I--revised recommendations. $J$ Inherit Metab Dis 34, 677-694.

Kuklenyik, Z., Calafat, A.M., Barr, J.R., Pirkle, J.L., 2011. Design of online solid phase extraction-liquid chromatography-tandem mass spectrometry (SPE-LC-MS/MS) hyphenated systems for quantitative analysis of small organic compounds in biological matrices. J. Separ. Sci. 34, 3606-3618.

Lanks, K.W., Turnbull, J.D., Aloyo, V.J., Dorwin, J., Papirmeister, B., 1975. Sulfur mustards induce neurite extension and acetylcholinesterase synthesis in cultured neuroblastoma-cells. Exp. Cell Res. 93, 355-362.

Li, C., Chen, J., Liu, Q., Xie, J., Li, H., 2013. Simultaneous quantification of seven plasma metabolites of sulfur mustard by ultra high performance liquid chromatography-tandem mass spectrometry. J. Chrom. B 917-918, 100-107. 
Liu, C.C., Liang, L.H., Xiang, Y., Yu, H.L., Zhou, S.K., Xi, H.L., Liu, S.L., Liu, J.Q., 2015. An improved method for retrospective quantification of sulfur mustard exposure by detection of its albumin adduct using ultra-high pressure liquid chromatography-tandem mass spectrometry. Anal. Bioanal. Chem. 407, 7037-7046.

Liu, Y., Song, Z., Chen, X., Zhu, Z., Zhang, L., Hong, Z., Chai, Y., 2020. Nuclear magnetic resonance-based plasma metabolomics revealed the protective effect of tea polyphenols on sulfur mustard-induced injury in rats. J Pharm Biomed Anal 186, 113278.

Łuczykowski, K., Warmuzińska, N., Bojko, B., 2021. Current approaches to the analysis of bile and the determination of bile acids in various biological matrices as supportive tools to traditional diagnostic testing for liver dysfunction and biliary diseases. Trends Anal. Chem. 142, 116307.

Malik, D.M., Rhoades, S., Weljie, A., 2018. Extraction and Analysis of Pan-metabolome Polar Metabolites by Ultra Performance Liquid Chromatography-Tandem Mass Spectrometry (UPLC-MS/MS). Bio Protoc 8.

Manandhar, E., Pay, A., Veress, L.A., Logue, B.A., 2018. Rapid analysis of sulfur mustard oxide in plasma using gas chromatography-chemical ionization-mass spectrometry for diagnosis of sulfur mustard exposure. J. Chrom. A 1572, 106-111.

Meng, W.Q., Zhang, H., Xiao, L., Chen, X.T., Sun, M.X., Xu, Q.Q., Cao, Y.B., Xiao, K., Li, Z.J., 2019. Visualization of sulfur mustard in living cells and whole animals with a selective and sensitive turn-on fluorescent probe. Sens. Actuators B Chem. 296.

Miller, R.T., Lau, S.S., Monks, T.J., 1995. Metabolism of 5-(Glutathione-S-YI)-AlphaMethyldopamine Following Intracerebroventricular Administration to Male Sprague-Dawley Rats. Chem. Res. Toxicol. 8, 634-641.

Missiaen, T., Soderstrom, M., Popescu, I., Vanninen, P., 2010. Evaluation of a chemical munition dumpsite in the Baltic Sea based on geophysical and chemical investigations. Sci Total Environ 408, 3536-3553.

Moreau, R., Claria, J., Aguilar, F., Fenaille, F., Lozano, J.J., Junot, C., Colsch, B., Caraceni, P., Trebicka, J., Pavesi, M., Alessandria, C., Nevens, F., Saliba, F., Welzel, T.M., Albillos, A., Gustot, T., Fernandez, J., Moreno, C., Baldassarre, M., Zaccherini, G., Piano, S., Montagnese, S., Vargas, V., Genesca, J., Sola, E., Bernal, W., Butin, N., Hautbergue, T., Cholet, S., Castelli, F., Jansen, C., Steib, C., Campion, D., Mookerjee, R., Rodriguez-Gandia, M., Soriano, G., Durand, F., Benten, D., Banares, R., Stauber, R.E., Gronbaek, H., Coenraad, M.J., Gines, P., Gerbes, A., Jalan, R., Bernardi, M., Arroyo, V., Angeli, P., Consortium, C.S.I.o.t.E.C., Grifols, C., European Foundation for the Study of Chronic Liver, F., 2020. Blood metabolomics uncovers inflammation-associated mitochondrial dysfunction as a potential mechanism underlying ACLF. J Hepatol 72, 688-701.

Mukherjee, S., Stone, W.L., Yang, H., Smith, M.G., Das, S.K., 2009. Protection of half sulfur mustard gas-induced lung injury in guinea pigs by antioxidant liposomes. J Biochem Mol Toxicol 23, 143-153.

Mukhopadhyay, S., Rajaratnam, V., Mukherjee, S., Smith, M., Das, S.K., 2006. Modulation of the expression of superoxide dismutase gene in lung injury by 2-chloroethyl ethyl sulfide, a mustard analog. J Biochem Mol Toxicol 20, 142-149.

Nagy, S.M., Golumbic, C., Stein, W., Fruton, J.S., Bergmann, M., 1946. The penetration of vesicant vapors into human skin. J. Gen. Physiol. 29, 441-469.

Nie, Z.Y., Liu, Q., Xie, J.W., 2011. Improvements in monitoring the N-terminal valine adduct in human globin after exposure to sulfur mustard and synthesis of reference chemicals. Talanta 85, 1154-1159.

Nobakht, B.F., Aliannejad, R., Rezaei-Tavirani, M., Arefi Oskouie, A., Naseri, M.T., Parastar, H., Aliakbarzadeh, G., Fathi, F., Taheri, S., 2016. NMR- and GC/MS-based metabolomics of sulfur mustard exposed individuals: a pilot study. Biomarkers 21, 479-489. 
Nobakht, B.F.M.G., Arefi Oskouie, A., Rezaei-Tavirani, M., Aliannejad, R., Taheri, S., Fathi, F., Taghi Naseri, M., 2017. NMR spectroscopy-based metabolomic study of serum in sulfur mustard exposed patients with lung disease. Biomarkers 22, 413-419.

Noort, D., Fidder, A., Degenhardt-Langelaan, C., Hulst, A.G., 2008. Retrospective detection of sulfur mustard exposure by mass spectrometric analysis of adducts to albumin and hemoglobin: an in vivo study. J. Anal. Toxicol. 32, 25-30.

Pantazides, B.G., Quinones-Gonzalez, J., Nazario, D.M.R., Crow, B.S., Perez, J.W., Blake, T.A., Johnson, R.C., 2019. A quantitative method to detect human exposure to sulfur and nitrogen mustards via protein adducts. J. Chrom. B 1121, 9-17.

Papirmeister, B., Gross, C.L., Meier, H.L., Petrali, J.P., Johnson, J.B., 1985. Molecular basis for mustard-induced vesication. Fundam. Appl. Toxicol. 5, 134-149.

Paromov, V., Kumari, S., Brannon, M., Kanaparthy, N.S., Yang, H., Smith, M.G., Stone, W.L., 2011. Protective effect of liposome-encapsulated glutathione in a human epidermal model exposed to a mustard gas analog. J Toxicol 2011, 1-11.

Paromov, V., Qui, M., Yang, H., Smith, M., Stone, W.L., 2008. The influence of N-acetyl-Lcysteine on oxidative stress and nitric oxide synthesis in stimulated macrophages treated with a mustard gas analogue. BMC Cell Biol 9.

Paromov, V., Suntres, Z., Smith, M., Stone, W.L., 2007. Sulfur mustard toxicity following dermal exposure: role of oxidative stress, and antioxidant therapy. J Burns Wounds 7, 60-85.

Pohanka, M., Sobotka, J., Stetina, R., 2011. Sulfur mustard induced oxidative stress and its alteration by epigallocatechin gallate. Toxicol Lett 201, 105-109.

Pohanka, M., Stetina, R., Svobodova, H., Ruttkay-Nedecky, B., Jilkova, M., Sochor, J., Sobotka, J., Adam, V., Kizek, R., 2013. Sulfur mustard causes oxidative stress and depletion of antioxidants in muscles, livers, and kidneys of Wistar rats. Drug Chem Toxicol 36, 270-276.

Qi, M., Xu, B., Wu, J., Zhang, Y., Zong, C., Chen, J., Guo, L., Xie, J., 2016. Simultaneous determination of sulfur mustard and related oxidation products by isotope-dilution LC-MS/MS method coupled with a chemical conversion. J. Chrom. B 1028, 42-50.

Rappeneau, S., Baeza-Squiban, A., Marano, F., Calvet, J., 2000. Efficient protection of human bronchial epithelial cells against sulfur and nitrogen mustard cytotoxicity using drug combinations. Toxicol Sci 58, 153-160.

Ravanat, J.L., Douki, T., Duez, P., Gremaud, E., Herbert, K., Hofer, T., Lasserre, L., SaintPierre, C., Favier, A., Cadet, J., 2002. Cellular background level of 8-oxo-7,8-dihydro-2'deoxyguanosine: an isotope based method to evaluate artefactual oxidation of DNA during its extraction and subsequent work-up. Carcinogenesis 23, 1911-1918.

Romano, J.A., Lukey, B.J., Salem, H., 2008. Chemical warfare agents: chemistry, pharmacology, toxicology, and therapeutics, 2nd ed. CRC Press Inc., Boca Raton.

Roser, M., Beal, D., Eldin, C., Gudimard, L., Caffin, F., Gros-Desormeaux, F., Leonco, D., Fenaille, F., Junot, C., Pierard, C., Douki, T., 2021. Glutathione conjugates of the mercapturic acid pathway and guanine adduct as biomarkers of exposure to CEES, a sulfur mustard analog. Anal. Bioanal. Chem. 413, 1337-1351.

Rowell, M., Kehe, K., Balszuweit, F., Thiermann, H., 2009. The chronic effects of sulfur mustard exposure. Toxicology 263, 9-11.

Sawyer, T.W., 1999. Toxicity of sulfur mustard in primary neuron culture. Toxicol. Vitro 13, 249-258.

Sezigen, S., Kenar, L., 2020. Recent sulfur mustard attacks in Middle East and experience of health professionals. Toxicol Lett 320, 52-57.

Sharma, D.R., Sunkaria, A., Bal, A., Bhutia, Y.D., Vijayaraghavan, R., Flora, S.J.S., Gill, K.D., 2009. Neurobehavioral impairments, generation of oxidative stress and release of proapoptotic factors after chronic exposure to sulphur mustard in mouse brain. Toxicol. Appl. Pharmacol 240, 208-218. 
Sheehan, D., Meade, G., Foley, V.M., Dowd, C.A., 2001. Structure, function and evolution of glutathione transferases: implications for classification of non-mammalian members of an ancient enzyme superfamily. Biochem. J. 360, 1-16.

Shohrati, M., Aslani, J., Eshraghi, M., Alaedini, F., Ghanei, M., 2008. Therapeutics effect of Nacetyl cysteine on mustard gas exposed patients: evaluating clinical aspect in patients with impaired pulmonary function test. Respir Med 102, 443-448.

Sidell, K.R., Montine, K.S., Picklo, M.J., Olsen, S.J., Amarnath, V., Montine, T.J., 2003. Mercapturate metabolism of 4-hydroxy-2-nonenal in rat and human cerebrum. $\mathrm{J}$ Neuropath Exp Neur 62, 146-153.

Strauss, K.A., Williams, K.B., Carson, V.J., Poskitt, L., Bowser, L.E., Young, M., Robinson, D.L., Hendrickson, C., Beiler, K., Taylor, C.M., Haas-Givler, B., Hailey, J., Chopko, S., Puffenberger, E.G., Brigatti, K.W., Miller, F., Morton, D.H., 2020. Glutaric acidemia type 1: Treatment and outcome of 168 patients over three decades. Mol Genet Metab 131, 325-340.

Sumner, L.W., Amberg, A., Barrett, D., Beale, M.H., Beger, R., Daykin, C.A., Fan, T.W., Fiehn, O., Goodacre, R., Griffin, J.L., Hankemeier, T., Hardy, N., Harnly, J., Higashi, R., Kopka, J., Lane, A.N., Lindon, J.C., Marriott, P., Nicholls, A.W., Reily, M.D., Thaden, J.J., Viant, M.R., 2007. Proposed minimum reporting standards for chemical analysis Chemical Analysis Working Group (CAWG) Metabolomics Standards Initiative (MSI). Metabolomics 3, 211-221.

Tabone, M., Bressa, C., Garcia-Merino, J.A., Moreno-Perez, D., Van, E.C., Castelli, F.A., Fenaille, F., Larrosa, M., 2021. The effect of acute moderate-intensity exercise on the serum and fecal metabolomes and the gut microbiota of cross-country endurance athletes. Sci Rep 11, 3558.

Talabani, J.M., Ali, A.I., Kadir, A.M., Rashid, R., Samin, F., Greenwood, D., Hay, A.W.M., 2018. Long-term health effects of chemical warfare agents on children following a single heavy exposure. Hum. Exp. Toxicol. 37, 836-847.

Tewari-Singh, N., Agarwal, C., Huang, J., Day, B.J., White, C.W., Agarwal, R., 2011. Efficacy of Glutathione in Ameliorating Sulfur Mustard Analog-Induced Toxicity in Cultured Skin Epidermal Cells and in SKH-1 Mouse Skin In Vivo. J. Pharmacol. Exp. Ther. 336, 450-459.

Thomsen, A.B., Eriksen, J., Smidt-Nielsen, K., 1998. Chronic neuropathic symptoms after exposure to mustard gas: A long-term investigation. J. Am. Acad. Dermatol. 39, 187-190.

Turnbull, J.D., Aloyo, V.J., Papirmei.B, 1973. Induction of axon growth and increased acetylcholinesterase production in mouse neuroblastoma cells by sulfur mustard. Proc. Feder. Amer. Soc. Exp. Biol. 32, 573.

Vanninen, P., Ostin, A., Beldowski, J., Pedersen, E.A., Soderstrom, M., Szubska, M., Grabowski, M., Siedlewicz, G., Czub, M., Popiel, S., Dziedzic, D., Jakacki, J., Paczek, B., Nawala, J., 2020. Exposure status of sea-dumped chemical warfare agents in the Baltic Sea. Mar Environ Res 161.

Varmazyar, M., Kianmehr, Z., Faghihzadeh, S., Ghazanfari, T., Ardestani, S.K., 2019. Time course study of oxidative stress in sulfur mustard analog 2-chloroethyl ethyl sulfide-induced toxicity. Int. Immunopharmacol. 73, 81-93.

Walterscheid, J.P., Nghiem, D.X., Kazimi, N., Nutt, L.K., McConkey, D.J., Norval, M., Ullrich, S.E., 2006. Cis-urocanic acid, a sunlight-induced immunosuppressive factor, activates immune suppression via the 5-HT2A receptor. Proc Natl Acad Sci U S A 103, 17420-17425.

Wattana, M., Bey, T., 2009. Mustard gas or sulfur mustard: an old chemical agent as a new terrorist threat. Prehosp Disaster Med 24, 19-29.

Wu, G.Y., Fang, Y.Z., Yang, S., Lupton, J.R., Turner, N.D., 2004. Glutathione metabolism and its implications for health. J. Nutr. 134, 489-492.

Xu, H., Nie, Z., Zhang, Y., Li, C., Yue, L., Yang, W., Chen, J., Dong, Y., Liu, Q., Lin, Y., Wu, B., Feng, J., Li, H., Guo, L., Xie, J., 2014. Four sulfur mustard exposure cases: Overall analysis of four types of biomarkers in clinical samples provides positive implication for early diagnosis and treatment monitoring. Toxicol. Rep. 1, 533-543. 
Yue, L.J., Zhang, Y.J., Chen, J., Zhao, Z.M., Liu, Q., Wu, R.Q., Guo, L., He, J., Zhao, J., Xie, J.W., Peng, S.Q., 2015. Distribution of DNA Adducts and Corresponding Tissue Damage of Sprague-Dawley Rats with Percutaneous Exposure to Sulfur Mustard. Chem. Res. Toxicol. 28, 532-540.

Zhang, Y.J., Yue, L.J., Nie, Z.Y., Chen, J., Guo, L., Wu, B.D., Feng, J.L., Liu, Q., Xie, J.W., 2014. Simultaneous determination of four sulfur mustard-DNA adducts in rabbit urine after dermal exposure by isotope-dilution liquid chromatography-tandem mass spectrometry. $\mathrm{J}$. Chrom. B 961, 29-35.

Zhu, H., Wang, N., Yao, L., Chen, Q., Zhang, R., Qian, J., Hou, Y., Guo, W., Fan, S., Liu, S., Zhao, Q., Du, F., Zuo, X., Guo, Y., Xu, Y., Li, J., Xue, T., Zhong, K., Song, X., Huang, G., Xiong, W., 2018. Moderate UV Exposure Enhances Learning and Memory by Promoting a Novel Glutamate Biosynthetic Pathway in the Brain. Cell 173, 1716-1727 e1717. 


\section{TABLES}

Table 1: Concentration (in $\mathrm{nM}$ ) of four biomarkers of exposure to CEES determined in the plasma of mice topically exposed to CEES. Plasma was collected after sacrifice after different periods and analysed by UHPLC-MS/MS with on-line SPE. The number on animals varied from 16 to 20 per group. The reported values are the means \pm SEM. The symbols for statistical significance of the differences at $p<0.05$ or $p<0.01$ are: ${ }^{*}$ and ${ }^{* *}$ for comparison with day $1 ;{ }^{\dagger}$ and ${ }^{\dagger \dagger}$ for comparison with day $3 ;{ }^{\ddagger}$ and ${ }^{\ddagger \ddagger}$ for comparison with day 7 ; and ${ }^{\S}$ and $\$ \S$ for comparison with day 14 .

\begin{tabular}{|c|c|c|c|c|}
\hline day & 1 & 3 & 7 & 14 \\
\hline GSH-CEES & $0.8 \pm 0.1 \S$ & $1.1 \pm 0.4$ & $1.3 \pm 0.5$ & $0.5 \pm 0.3^{*}$ \\
\hline Cys-CEES & $42.9 \pm 3.3^{\ddagger \pm, \S \S}$ & $37.6 \pm 3.2^{\ddagger, \S \S}$ & $14.8 \pm 4.3^{* *, \dagger}$ & $3.9 \pm 2.0^{* *},+\dagger$ \\
\hline NAC-CEES & $41.0 \pm 2.9^{\dagger, \pm \neq, \S \S}$ & $17.3 \pm 1.1^{* *}, \pm \neq, \S \S$ & $3.8 \pm 0.5^{* *},+\dagger$ & $5.7 \pm 2 .^{* *},+\dagger$ \\
\hline N7Gua-CEES & $34.7 \pm 2.9+\dagger, \neq \pm, \S \S$ & $4.2 \pm 0.4^{*}, \pm, \S \S$ & $0.8 \pm 0.1^{* *, \dagger}$ & $0.3 \pm 0.1^{* *}, t \dagger$ \\
\hline
\end{tabular}




\section{FIGURES}

Figure 1: Heatmap showing the modulation of the plasma levels of the top 50 impacted metabolites (according to ANOVA p-values) upon dermal exposure of hairless mice to CEES. The heatmap depicts high (red) and low (blue) relative abundances (log transformed) of metabolites from the most informative HILIC(-) dataset. NE: non exposed mice.

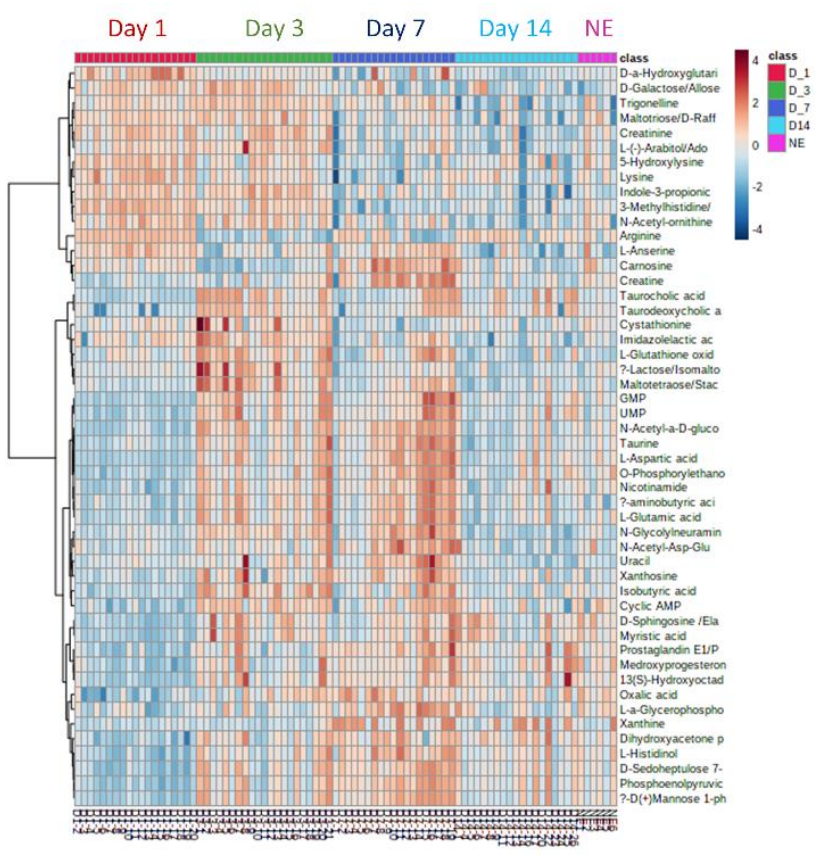


Figure 2: variation of the concentration of a series of plasma metabolites following exposure to CEES. The metabolites underwent either a) decrease or b) increase in their concentration levels. NE: non exposed mice.

a)
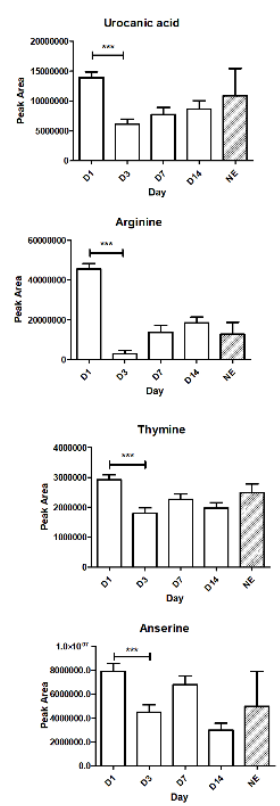

b)
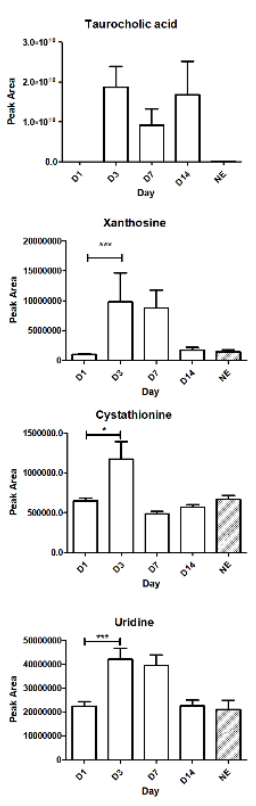
Figure 3: Levels of biomarkers of exposure to CEES in brains of exposed mice. Brains were collected after sacrifice after different periods. Half of the organ was used for DNA extraction and the other was homogenized in chloroform:methanol and extracted with water. Samples were then analysed by UHPLC-MS/MS with on-line SPE. A) Amount of N7Gua-CEES adducts measured either in the DNA of the organ (expressed in adduct per $10^{6}$ bases) or detected in extract of the whole organ (expressed in $\mathrm{fmol} / \mathrm{mg}$ tissue) b) Concentration of $\mathrm{GSH}$, Cys and NAC conjugates to CEES in brain extracts (expressed in $\mathrm{fmol} / \mathrm{mg}$ ). The number on animals varied from 16 to 20 per group. The reported values are the means \pm SEM. The symbols for statistical significance of the differences at $p<0.05$ or $p<0.01$ are: * and ${ }^{* *}$ for comparison with day $1 ;{ }^{\dagger}$ and ${ }^{\dagger \dagger}$ for comparison with day $3 ;{ }^{\ddagger}$ and ${ }^{\ddagger}$ for comparison with day 7 ; and ${ }^{\S}$ and $\$ \S$ for comparison with day 14 .
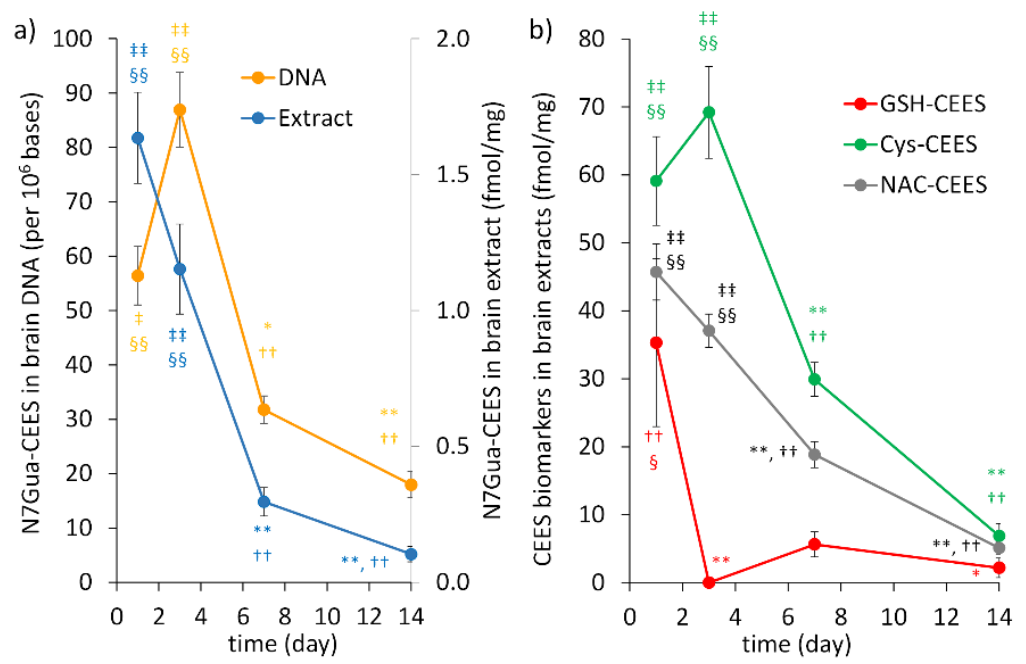
Evidence for the systemic diffusion of (2-chloroethyl)-ethyl-sulfide, a sulfur mustard analog, and its deleterious effects in brain

By Marie Roser, Daniel Léonço, Fanny Caffin, Fanny Gros-Désormeaux, Camille Eldin, David Béal, Sadia Ouzia, Christophe Junot, François Fenaille, Christophe Piérard and Thierry Douki

\section{Supplementary data}

Content :

Table S1. Annotated and significant metabolites between non-exposed mice and day 1 after CEES exposure.

Table S2. Annotated and significant metabolites between day 1 and day 3 after CEES exposure.

Table S3. Annotated and significant metabolites between day 3 and day 7 after CEES exposure.

Figure S1. Summary of metabolic pathway enrichment analysis performed in MetaboAnalyst using the metabolites from Table S1 that are altered between day 1 and day 3 after CEES exposure. 
Table S1. Annotated and significant metabolites between non-exposed mice and day 1 after CEES exposure.

Fold changes $>1.5$, p-values $<0.05$ (Wilcoxon with Benjamini-Hochberg correction).

\begin{tabular}{|c|c|c|c|c|}
\hline HLLC(-) conditions & Fold change D1/NE & $\log 2(\mathrm{FC})$ & p.ajusted & Identification status \\
\hline Cyclic AMP & 0.1013 & -3.3034 & 0.014461 & $a, b$ \\
\hline Phosphoenolpyruvic acid & 0.1523 & -2.715 & 0.00025799 & $a, b$ \\
\hline GMP & 0.15345 & -2.7042 & 0.00041656 & $a, b, c$ \\
\hline Medroxyprogesterone & 0.17092 & -2.5486 & 0.00075628 & $a, b$ \\
\hline UMP & 0.19061 & -2.3913 & 0.028242 & $a, b, c$ \\
\hline L-Histidinol & 0.19801 & -2.3364 & 0.00075628 & $a, b$ \\
\hline Hexose-Phosphate & 0.20741 & -2.2695 & 0.00012959 & $a, b$ \\
\hline D-Sedoheptulose 7-phosphate & 0.20951 & -2.2549 & 0.00075628 & $a, b$ \\
\hline Taurocholic acid & 0.2287 & -2.1285 & 0.0077006 & $a, b, c$ \\
\hline Dihydroxyacetone phosphate/Diglycolic acid & 0.23164 & -2.1101 & 0.0055025 & $a, b$ \\
\hline Prostaglandin E1/Prostaglandin B1/Prostagla & 0.247 & -2.0174 & 0.0031558 & $a, b$ \\
\hline D-Sphingosine /Elaidic acid/trans-Vaccenic a & 0.27309 & -1.8726 & $1.5483 \mathrm{E}-05$ & $a, b$ \\
\hline Disaccharide & 0.30244 & -1.7253 & 0.033416 & $a, b$ \\
\hline Cholic acid & 0.33332 & -1.585 & 0.037612 & $a, b, c$ \\
\hline cis-8,11,14-Eicosatrienoic acid & 0.35115 & -1.5098 & $4.2134 \mathrm{E}-05$ & $a, b$ \\
\hline Myristic acid & 0.36217 & -1.4653 & $4.2134 \mathrm{E}-05$ & $a, b$ \\
\hline 13(S)-Hydroxyoctadeca-9Z,11E-dienoic acid & 0.38152 & -1.3902 & $3.0085 \mathrm{E}-05$ & $a, b, c$ \\
\hline gamma-Linolenic acid & 0.38596 & -1.3735 & 0.00020346 & $a, b$ \\
\hline L-Aspartic acid & 0.46681 & -1.0991 & $2.1541 \mathrm{E}-05$ & $a, b, c$ \\
\hline Nicotinamide & 0.48102 & -1.0558 & 0.0077006 & $a, b$ \\
\hline O-Phosphorylethanolamine & 0.5122 & -0.96523 & 0.0022392 & $a, b, c$ \\
\hline Diethyladipate/Nonanoic acid & 0.51913 & -0.94582 & 0.00020346 & $a, b$ \\
\hline N-Acetyl-a-D-glucosamine 1-phosphate & 0.51941 & -0.94505 & 0.0040478 & $a, b, c$ \\
\hline Isobutyric acid & 0.53237 & -0.90949 & 0.0047267 & $a, b, c$ \\
\hline 4-Methyl-2-oxovaleric acid/2-Ketohexanoic : & 0.5418 & -0.88417 & 0.00020346 & $a, b$ \\
\hline cis-5,8,11,14,17-Eicosapentaenoic acid & 0.54188 & -0.88395 & 0.00236 & $a, b, c$ \\
\hline N-Acetylglycine & 0.55797 & -0.84175 & 0.0024695 & $a, b, c$ \\
\hline Guanidinosuccinic acid & 0.56244 & -0.83023 & 0.02684 & $a, b$ \\
\hline Azelaic acid & 0.56474 & -0.82435 & 0.0055025 & $a, b, c$ \\
\hline N-Acetyl-L-asparagine & 0.56491 & -0.8239 & 0.0027245 & $a, b, c$ \\
\hline D-erythro-Dihydrosphingosine (Sphinganine) & 0.59419 & -0.751 & 0.00075628 & $a, b$ \\
\hline $\mathrm{N}$-acetyl-DL-Valine & 0.62656 & -0.67449 & 0.0079669 & $a, b$ \\
\hline Methyl acetoacetate & 0.64059 & -0.64252 & 0.00075628 & $a, b, c$ \\
\hline Isoleucine/Leucine & 0.64379 & -0.63534 & 0.0077006 & $a, b, c$ \\
\hline N-Isobutyrylglycine & 0.65029 & -0.62084 & 0.011653 & $a, b, c$ \\
\hline Methylhistidine & 1.5362 & 0.61935 & 0.00066837 & $a, b, c$ \\
\hline Hexose & 1.5709 & 0.65159 & 0.00020346 & $a, b, c$ \\
\hline 5-Hydroxylysine & 1.5772 & 0.65735 & 0.025891 & $a, b, c$ \\
\hline 2,6-Dihydroxybenzoic acid & 1.5874 & 0.66665 & 0.022888 & $a, b$ \\
\hline L-Anserine & 1.5944 & 0.67305 & 0.0055286 & $a, b, c$ \\
\hline 4-Hydroxy-3-methoxyphenylglycol sulfate & 1.637 & 0.71105 & 0.0055286 & $a, b, c$ \\
\hline Citric acid//socitric acid & 1.6997 & 0.76529 & 0.0047375 & $a, b, c$ \\
\hline $\mathrm{L}(+)$ arabinose/D-Xylulose/D-Arabinose & 1.7574 & 0.8134 & 0.042033 & $a, b, c$ \\
\hline D-Arabinose $/ \mathrm{L}(+)$ arabinose & 1.814 & 0.8592 & 0.015196 & $a, b, c$ \\
\hline Glutaconic acid & 1.9477 & 0.9618 & 0.024794 & $a, b, c$ \\
\hline Hydroxyglutaric acid & 2.215 & 1.1473 & 0.0075293 & $a, b, c$ \\
\hline Indole-3-propionic acid/Methyl indole-3-acє & 2.2311 & 1.1577 & 0.00011977 & $a, b, c$ \\
\hline D-(-)-Quinic acid & 2.2457 & 1.1672 & 0.015196 & $a, b, c$ \\
\hline L-Glutathione oxidized & 2.3602 & 1.2389 & 0.037612 & $a, b, c$ \\
\hline Arginine & 3.5531 & 1.8291 & 0.0002166 & $a, b, c$ \\
\hline
\end{tabular}

$\begin{array}{lcccc}\text { C18(+) conditions } & \text { Fold change D1/NE } & \log 2(\mathrm{FC}) & \text { p.ajusted } & \text { Identification status } \\ \text { Nalapha-Acetyl-L-asparagine } & 0.01481 & -6.0773 & 0.024113 & \mathrm{a}, \mathrm{b} \\ \text { Taurocholic-acid } & 0.05335 & -4.2284 & 0.024113 & \mathrm{a}, \mathrm{b}, \mathrm{c} \\ \text { Indolelactic-acid } & 0.34417 & -1.5388 & 0.029765 & \mathrm{a}, \mathrm{b}, \mathrm{c} \\ \text { Nicotinamide } & 0.42485 & -1.235 & 0.017882 & \mathrm{a}, \mathrm{b}, \mathrm{c} \\ \text { 5-hydroxytryptophan } & 0.44083 & -1.1817 & 0.02428 & \mathrm{a}, \mathrm{b} \\ \text { Propionylcarnitine } & 0.44768 & -1.1595 & 0.017882 & \mathrm{a}, \mathrm{b}, \mathrm{c} \\ \text { Riboflavin } & 0.45643 & -1.1315 & 0.024113 & \mathrm{a}, \mathrm{b}, \mathrm{c} \\ \text { Hexanoylcarnitine } & 0.47746 & -1.0665 & 0.024113 & \mathrm{a}, \mathrm{b}, \mathrm{c} \\ \text { Allantoic-acid } & 0.59578 & -0.74716 & 0.024113 & \mathrm{a}, \mathrm{b} \\ \text { Acetyl-L-carnitin } & 0.64446 & -0.63384 & 0.024113 & \mathrm{a}, \mathrm{b}, \mathrm{c}\end{array}$

Metabolite identification status

a. Based on accurate mass matching

c. Based on MS2 spectral similarity with that of an authentic standard 
Table S2. Annotated and significant metabolites between day 1 and day $\mathbf{3}$ after CEES exposure.

Fold changes $>1.5$, p-values $<0.05$ (Wilcoxon with Benjamini-Hochberg correction)

\begin{tabular}{|c|c|c|c|c|}
\hline HLLC(-) conditions & Fold Change D3/D1 & $\log 2(F C)$ & p.adjusted & Identification status \\
\hline Arginine & 0.066097 & -3.9193 & 3.25E-06 & $a, b, c$ \\
\hline 4-Imidazoleacrylic acid (urocanic acid) & 0.44291 & -1.1749 & $8.00 \mathrm{E}-06$ & $a, b, c$ \\
\hline Hydroxyglutaric acid & 0.51393 & -0.96037 & 0.00021442 & $a, b, c$ \\
\hline L-Anserine & 0.56527 & -0.823 & 0.00021442 & $a, b, c$ \\
\hline Corticosterone/21-Deoxycortisol & 0.57514 & -0.798 & 0.015843 & $a, b$ \\
\hline Sphingosine 1-phosphate & 0.57697 & -0.79343 & 0.0012463 & $a, b, c$ \\
\hline $\begin{array}{l}\text { Glutaconic acid } \\
\text { Thymine }\end{array}$ & 0.58865 & -0.76451 & $\begin{array}{r}0.0027181 \\
0\end{array}$ & $a, b, c$ \\
\hline $\begin{array}{l}\text { Thymine } \\
\text { Carnosine }\end{array}$ & 0.61656 & -0.6977 & 0.000024844 & $a, b, c$ \\
\hline $\begin{array}{l}\text { Carnosine } \\
\text { D-(-)Quinic acid }\end{array}$ & $\begin{array}{l}0.62023 \\
0.62992\end{array}$ & $\begin{array}{l}-0.069912 \\
-{ }^{-0.66675}\end{array}$ & $\begin{array}{l}0.000039292 \\
4.99--02\end{array}$ & $\begin{array}{l}a, b \\
a, b, c\end{array}$ \\
\hline 5-Hydroxylysine & 0.63411 & -0.65718 & $2.00 \mathrm{E}-03$ & $a, b, c$ \\
\hline Deoxyuridine & 0.66361 & -0.5916 & 0.000062734 & $a, b$ \\
\hline N-Acetyl-L-aspartic acid & 1.5019 & 0.58677 & 0.00033479 & $a, b, c$ \\
\hline Muramic acid & 1.5059 & 0.59062 & 0.048692 & $a, b$ \\
\hline Phosphoserine & 1.5473 & 0.62978 & 0.0068168 & $a, b, c$ \\
\hline D-Saccharic acid & 1.5538 & 0.6358 & 0.00010908 & $a, b, c$ \\
\hline Taurine & 1.5574 & 0.63917 & 0.00022214 & $a, b, c$ \\
\hline $\begin{array}{l}\text { Azelaic acid } \\
\text { Galactonic acid }\end{array}$ & $\begin{array}{l}1.6277 \\
1.64418\end{array}$ & 0.70281 & $\begin{array}{l}0.00015082 \\
0.00014052\end{array}$ & $a, b, c$ \\
\hline $\begin{array}{l}\text { Galalatonnic acid } \\
\text { N-Gycolyneuraminic acid }\end{array}$ & $\begin{array}{l}1.66418 \\
1.6741\end{array}$ & $\begin{array}{l}0.717528 \\
0.74339\end{array}$ & $\begin{array}{l}0.0000140052 \\
0.00000001\end{array}$ & $a, b, c$ \\
\hline $\mathrm{N}$ acetyl L glutamine & $\begin{array}{l}1.041 \\
1.7886\end{array}$ & $\begin{array}{l}0.74339 \\
0.8388\end{array}$ & $\begin{array}{l}0.0000000001 \\
0.00005379\end{array}$ & $\begin{array}{l}a, b, c \\
a, b, c\end{array}$ \\
\hline Cystathionine & 1.8062 & 0.85297 & 0.019735 & $a, b, c$ \\
\hline aminobutyric acid & 1.8312 & 0.8728 & 0.000053687 & $a, b$ \\
\hline L-Glutamic acid & 1.8698 & 0.90286 & 0.00002877 & $a, b, c$ \\
\hline Uridine & 1.8791 & 0.91003 & 0.00099663 & $a, b, c$ \\
\hline N-Acetyl-L-asparagine & 1.9716 & 0.97934 & 0.00005379 & $a, b, c$ \\
\hline 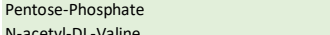 & 2.0154 & 1.0111 & 0.03016 & $a, b, c$ \\
\hline $\begin{array}{l}\text { N-acetyy-DL-Valine } \\
\text { O-phosphorlethanolamine }\end{array}$ & $\begin{array}{l}2.0768 \\
2.3198\end{array}$ & 1.0544 & $2.72 \mathrm{E}-03$ & $a, b$ \\
\hline $\begin{array}{l}\text { O-Phosphorrlethanolamine } \\
\text { N-Acty-glutamic acid }\end{array}$ & $\begin{array}{l}2.3198 \\
2.3435\end{array}$ & $\begin{array}{l}1.214 \\
1.2286\end{array}$ & $\begin{array}{l}1.50 E^{-0.5} \\
0.00051833\end{array}$ & $a, b, c$ \\
\hline 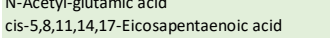 & $\begin{array}{l}2.3435 \\
2.4316\end{array}$ & $\begin{array}{l}1.2286 \\
1.2819\end{array}$ & $\begin{array}{l}0.000018383 \\
0.0003671\end{array}$ & $\begin{array}{l}a, b, c \\
a, b, c\end{array}$ \\
\hline Morphine-6-D-glucuronide & 2.5591 & 1.3556 & 0.013793 & $a, b, c$ \\
\hline 4-Pyridoxic acid & 2.5748 & 1.3645 & 0.000011774 & $a, b, c$ \\
\hline Guanidinosuccinic acid & 2.5944 & 1.3754 & 0.00049995 & $a, b$ \\
\hline L-Aspartic acid & 2.8371 & 1.5044 & 1.6339E-07 & $a, b, c$ \\
\hline N-Acetyl-a-D-g-gucosamine 1-phosphate & 3.0295 & 1.5991 & 0.00002877 & $a, b, c$ \\
\hline 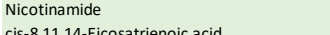 & 3.1556 & 1.6579 & $3.25 E-06$ & $a, b$ \\
\hline $\begin{array}{l}\text { cis-8,11,14-Eicosatrienoic acid } \\
\text { Succiic acid }\end{array}$ & $\begin{array}{l}3.159 \\
3.196\end{array}$ & $\begin{array}{l}1.6595 \\
1.6763\end{array}$ & $\begin{array}{l}7.8912 E-06 \\
0.0007059\end{array}-1050$ & $a, b$ \\
\hline $\begin{array}{l}\text { Succinic acid } \\
\text { gamma-Linolenic acid }\end{array}$ & $\begin{array}{l}3.196 \\
3.2921\end{array}$ & $\begin{array}{l}1.66763 \\
1719\end{array}$ & $\begin{array}{l}0.000077059 \\
0.000007364\end{array}$ & $a, b, c$ \\
\hline 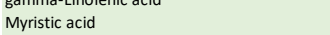 & $\begin{array}{l}3.2921 \\
3.6533\end{array}$ & $\begin{array}{l}1.1199 \\
1.8692\end{array}$ & $\begin{array}{ll}0.000000 / 364 \\
3.998-06\end{array}$ & $\begin{array}{l}\begin{array}{l}a, b \\
a, b\end{array} \\
a\end{array}$ \\
\hline 13(s)-Hydroxyoctadeca-9z,11E-dienoic acid & 3.8278 & 1.9365 & $2.41 \mathrm{E}-06$ & $a, b, c$ \\
\hline D-Sphingosine /Elaidic acid/trans-Vaccenic a & 3.8995 & 1.9633 & $3.78 \mathrm{E}-06$ & $a, b$ \\
\hline Disaccharide & 3.9478 & 1.981 & $1.24 \mathrm{E}-04$ & $a, b$ \\
\hline 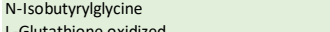 & 3.9794 & 1.9925 & $1.47 \mathrm{E}-05$ & $a, b, c$ \\
\hline L-Glutathione oxidizized & 4.0439 & 2.0158 & $1.16 \mathrm{E}-04$ & $a, b, c$ \\
\hline $\begin{array}{l}\text { Medroxyprogesterone } \\
\text { Isobutricarid }\end{array}$ & 5.0897 & $\begin{array}{l}2.3476 \\
2.458\end{array}$ & $\begin{array}{l}4.41 \mathrm{E}-04 \\
24 \mathrm{E}-06\end{array}$ & $a, b$ \\
\hline $\begin{array}{l}\text { Issobutryic acid } \\
\text { L-Histidinol }\end{array}$ & $\begin{array}{l}5.486 \\
5.7465\end{array}$ & $\begin{array}{l}2.4558 \\
2.5227\end{array}$ & $\begin{array}{l}2.44 E-06 \\
3.03 E-05\end{array}$ & $\begin{array}{l}a, b, c \\
a, b\end{array}$ \\
\hline $\begin{array}{l}\text { P-Histidinol E1/Prostaglandin B1/Prostagle } \\
\text { Prostalandin } 1 \text { Prosin }\end{array}$ & $\begin{array}{l}5.7659 \\
6.1569\end{array}$ & $\begin{array}{l}2.5227 \\
2.6222\end{array}$ & $\begin{array}{l}3.003 E-05 \\
0.0027181\end{array}$ & $\begin{array}{l}a, b \\
a, b\end{array}$ \\
\hline Dihydroxyacetone phosphate/Diglycolic acic & 7.1984 & 2.8477 & $1.41 E-04$ & $a, b$ \\
\hline D-Sedoheptulose 7-phosphate & 8.5937 & 3.1033 & $8.8833 E-06$ & $a, b$ \\
\hline Xanthosine & 10.256 & 3.3584 & 0.0008667 & $a, b$ \\
\hline Hexose-Phosphate & 10.742 & 3.4252 & 7.24122E-06 & $a, b$ \\
\hline $\begin{array}{l}\text { Cyclic AMP } \\
\end{array}$ & 13.778 & 3.7842 & 1.6339E-07 & $a, b$ \\
\hline $\begin{array}{l}\text { Phosphoenolpyruvic acid } \\
\text { She }\end{array}$ & 14.563 & 3.8642 & 0.000021656 & $a, b$ \\
\hline $\begin{array}{l}\text { Stachyose } \\
\text { Cholic acid }\end{array}$ & $\begin{array}{l}19.606 \\
27.856\end{array}$ & $\begin{array}{l}4.2932 \\
477999\end{array}$ & $\begin{array}{l}7.89 \mathrm{E}-06 \\
0.0002877\end{array}$ & $a, b, c$ \\
\hline $\begin{array}{l}\text { Cholil acid } \\
\text { UDP-N-acetvglucosamin }\end{array}$ & $\begin{array}{l}27.856 \\
30571\end{array}$ & $\begin{array}{l}4.7999 \\
4.9341\end{array}$ & $\begin{array}{l}0.00002877 \\
7.51-04\end{array}$ & $a, b, c$ \\
\hline & $\begin{array}{l}32.903 \\
32.903\end{array}$ & $\begin{array}{l}4.5941 \\
5.0401\end{array}$ & $\begin{array}{l}7.51-0.04 \\
2.4073 E-06\end{array}$ & $\begin{array}{l}a, b, c \\
a, b, c\end{array}$ \\
\hline 5-Methyldeoxycytidine & 140.67 & 7.1362 & $3.94 E-04$ & $a, b$ \\
\hline & 235.48 & 7.8794 & $9.43 E-06$ & $a, b, c$ \\
\hline Uridine 5'-diphosphogalactose & 711.04 & 9.4738 & 0.00026195 & $a, b, c$ \\
\hline $\begin{array}{l}\text { Taurocholic acid } \\
\text { Taurodoxycholic a }\end{array}$ & $\begin{array}{l}1704.4 \\
1837.5\end{array}$ & $\begin{array}{l}10.735 \\
10.844\end{array}$ & $\begin{array}{l}1.13 E-07 \\
3.25-06\end{array}$ & $\begin{array}{l}a, b, c \\
a, b\end{array}$ \\
\hline & & & & \\
\hline
\end{tabular}

\begin{tabular}{|c|c|c|c|c|}
\hline $\mathrm{C} 18(+)$ conditions & Fold Change D3/D1 & $\log 2(F C)$ & p.adjusted & Identification status \\
\hline N-alpha-acetyl-L-arginine & 0.5843 & -0.77521 & $1.98 \mathrm{E}-03$ & \\
\hline 4-Imidazoleacrylic-acid-(urocanic-acid) & 0.59193 & -0.75651 & 4.966-05 & $a, b, c$ \\
\hline NG-Acetyl-L-lysine & 0.65282 & -0.61525 & $3.82 E-04$ & $a, b, c$ \\
\hline Acetyl-L-carnitine & 1.5134 & 0.59782 & 7.9642E-05 & $a, b, c$ \\
\hline $\begin{array}{l}\text { Uracil } \\
6 \text { 6-Hydroxypyridine-2-carboxylic-acid/3-Hydroxyii }\end{array}$ & 1.6647 & 0.73526 & 0.022903 & $a, b, c$ \\
\hline 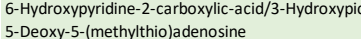 & 1.7467 & $\begin{array}{l}0.80459 \\
0.8253\end{array}$ & $\begin{array}{l}0.0082908 \\
0.001638\end{array}$ & $a, b$ \\
\hline $\begin{array}{l}\text { 5-Deexo-y-5-methyythio)adenosine } \\
\text { Allantoc-acid }\end{array}$ & 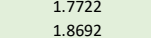 & 0.82553 & $\begin{array}{l}0.0006388 \\
2.3845-06\end{array}$ & $a, b, c$ \\
\hline Glutathione & 1.9318 & 0.94992 & $\begin{array}{l}2.33455-06 \\
0.00038243\end{array}$ & $\begin{array}{l}a, b \\
a, b, c\end{array}$ \\
\hline 4-Guanidinobutyric-acid & 1.9338 & 0.95141 & 0.0067105 & $a, b, c$ \\
\hline Octanoylcarnitine & 2.0873 & 1.0616 & 0.0016388 & $a, b, c$ \\
\hline Propionylcarnitine & 2.0935 & 1.0659 & 0.00002314 & $a, b, c$ \\
\hline alpha-Methyhistamine/3-Methylhistamine & 2.2114 & 1.1449 & 0.0039612 & $a, b, c$ \\
\hline Nicotinamide & 2.2888 & 1.1946 & $8.4012 \mathrm{E}-06$ & $a, b, c$ \\
\hline $\begin{array}{l}\text { 4-Pyridoxic--acid- } \\
\text { 5-hydroxtryotohan }\end{array}$ & 2.5335 & $\begin{array}{l}1.3412 \\
1.3007\end{array}$ & $2.3845 \mathrm{E}-06$ & $\mathrm{a}, \mathrm{b}$ \\
\hline $\begin{array}{l}\text { S-hydroxytryptophan } \\
\text { Adenine }\end{array}$ & $\begin{array}{l}2.6221 \\
2.7396\end{array}$ & $\begin{array}{l}1.3907 \\
1.454\end{array}$ & $\begin{array}{l}0.004747 \\
79642-05\end{array}$ & $a, b$ \\
\hline $\begin{array}{l}\text { Aemine } \\
\text { Adenosine }\end{array}$ & 2.8914 & $\begin{array}{l}1.454 \\
1.5318\end{array}$ & 0.00019561 & a, \\
\hline Disaccharide & 3.5956 & 1.8462 & 0.00049871 & $a, b$ \\
\hline Indolelactic-acid & 3.9772 & 1.9918 & 0.012103 & $a, b, c$ \\
\hline Hexanoylcarnitine & 4.9322 & 2.3022 & $3.2394 \mathrm{E}-06$ & $a, b, c$ \\
\hline Riboflavin & 5.9475 & 2.5723 & $1.1344 \mathrm{E}-05$ & $a, b, c$ \\
\hline Xanthosine & 12.087 & 3.5954 & 0.0002588 & $a, b, c$ \\
\hline $\begin{array}{l}\text { Nalpha-cactety-l-assparagine } \\
\text { Taurochlicacid }\end{array}$ & $\begin{array}{l}83.092 \\
5111.4\end{array}$ & $\begin{array}{l}6.3776 \\
8.9983\end{array}$ & $\begin{array}{l}1.640118-06 \\
2.838 E-08\end{array}$ & $\begin{array}{l}a, b \\
a, b, c\end{array}$ \\
\hline Taurodeoxycholic-acid & 1575 & 10.621 & $1.64011-06$ & $a, b, c$ \\
\hline
\end{tabular}

Metabolite identification status

b. Based on chromatographic retention time similarity with that of an authentic standard

c. Based on MS2 spectral similarity with that of an authentic standard 
Table S3. Annotated and significant metabolites between day 3 and day 7 after CEES exposure. Fold changes $>1.5$, p-values $<0.05$ (Wilcoxon with Benjamini-Hochberg correction).

\begin{tabular}{|c|c|c|c|c|c|c|c|c|c|}
\hline HILIC(-) conditions & Fold Change D7/D3 & $\log 2(\mathrm{FC})$ & p.adjusted & Identification status & C18(+) conditions & Fold Change D7/D3 & $\log 2(\mathrm{FC})$ & p.adjusted & Identification status \\
\hline Disaccharides & 0.25494 & -1.9718 & 0.0002821 & & Disaccharides & 0.30902 & -1.6942 & 0.043942 & $a, b$ \\
\hline Cystathionine & 0.41459 & -1.2702 & $1.23 \mathrm{E}-04$ & $a, b, c$ & 4-Guanidinobutyric-acid & 0.43931 & & 0.02458 & \\
\hline D-Raffinose & 0.49893 & -1.0031 & $8.21 \mathrm{E}-03$ & $a, b, c$ & Adenosine & 0.49276 & -1.0211 & 0.02458 & $a, b$ \\
\hline Indole-3-propionic acid/Methyl inde & 0.55325 & -0.854 & 0.0082054 & $a, b, c$ & Aminohippuric-acid & 0.59494 & -0.74918 & 0.018407 & $\mathrm{a}, \mathrm{b}$ \\
\hline $\begin{array}{l}\text { 5-Mydroxylysine } \\
\text { Methylintidine }\end{array}$ & $\begin{array}{l}0.5603 \\
0.56075\end{array}$ & 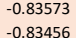 & $\begin{array}{c}0.019063 \\
4.4617 \mathrm{E}-05\end{array}$ & $\begin{array}{l}a, b, c \\
a, b \\
a\end{array}$ & 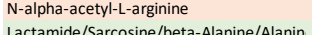 & 0.64845 & -0.62494 & $\begin{array}{l}0.041023 \\
0.025615\end{array}$ & $a, b$ \\
\hline $\begin{array}{l}\text { Methhlihistidine } \\
\text { L-(-)Arabitol/Adonitol/D-(+)-Arabitc }\end{array}$ & 0.56075 & 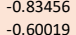 & $\begin{array}{l}4.46177-05 \\
0.066763\end{array}$ & $a, b, c$ & $\begin{array}{l}\text { Lactamide/Sarcosine/beta-Alanine/Alanin } \\
\text { Benzyy-alcohol }\end{array}$ & 1.6938 & 0.71349 & 0.025615 & $a, b$ \\
\hline 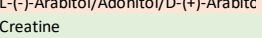 & $\begin{array}{l}0.6567 \\
1.5653\end{array}$ & $\begin{array}{l}-0.60019 \\
0.64646\end{array}$ & $\begin{array}{l}0.00604633 \\
0.0082054\end{array}$ & $\begin{array}{l}a, b, c \\
a, b, c\end{array}$ & $\begin{array}{l}\text { Benzzy-arcohol } \\
\text { Serotonin-hydrochloride }\end{array}$ & $\begin{array}{l}2.5138 \\
3.0428\end{array}$ & $\begin{array}{l}1.3 .398 \\
1.6054\end{array}$ & $\begin{array}{l}0.0094991 \\
0.018407\end{array}$ & $\begin{array}{l}a, b \\
a, b, c\end{array}$ \\
\hline L-a-Glycerophosphorylcholine & 1.5666 & 0.64764 & 0.006656 & $a, b$ & & & & & \\
\hline Benzoic acid/4-Hydroxybenzzaldehyd & 1.593 & 0.67174 & 0.0082054 & $a, b$ & Metabolite identification status & & & & \\
\hline Carnosine & 2.7684 & 1.4691 & 0.00010262 & $a, b$ & a. Based on accurate mass matching & & & & \\
\hline Prostaglandin E1/Prostaglandin B1/F & 3.5546 & 1.8297 & 0.01364 & $a, b$ & b. Based on chromatographic retention & illarity & rauthe & tandard & \\
\hline Xanthine & 91.915 & & 4.4617E-05 & & c. Based on MS2 spectral similarity with tha & In authentic s & & & \\
\hline
\end{tabular}


Figure S1. Summary of metabolic pathway enrichment analysis performed in MetaboAnalyst using the metabolites from Table $S 1$ that are altered between day 1 and day 3 after CEES exposure. The color and size of each circle are based on p-value and pathway impact value, respectively.

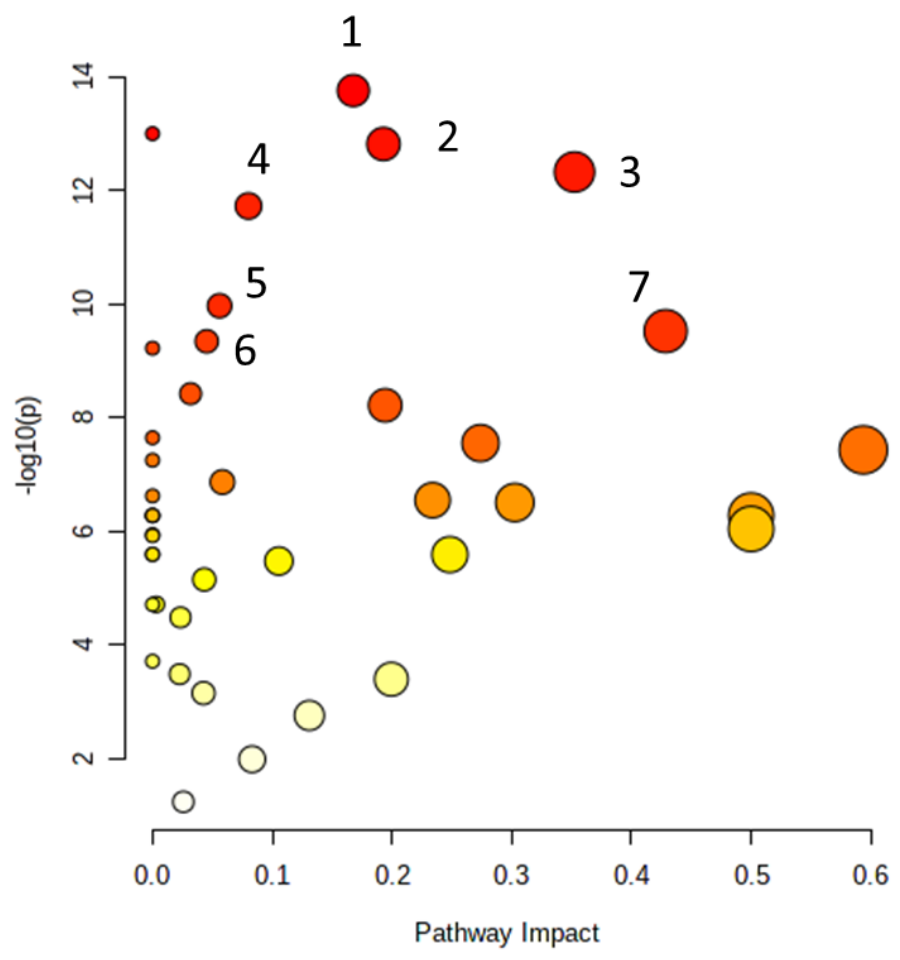

1. Arginine and proline metabolism

2. Arginine biosynthesis

3. Histidine metabolism

4. Purine metabolism

5. beta-alanine metabolism

6. Primary bile acid synthesis

7. Taurine and hypotaurine metabolism 